\title{
Waste Not, Want Not: The Marketable Product Rule Violates Public Policy Against Waste of Natural Gas Resources
}

\author{
John W. Broomes ${ }^{*}$
}

\section{INTRODUCTION}

The courts of several natural gas-producing states have, over the years, adopted what is often referred to as the "marketable product rule" or "first marketable product doctrine" (hereinafter referred to, in all its various forms, as the "Marketable Product Rule" or the "Rule"). ${ }^{1}$ The Marketable Product Rule is a judicially crafted doctrine applied to natural gas royalty provisions. The Rule requires the lessee under an oil and gas lease to bear all production and post-production expenses incurred until the gas is considered "marketable." 2 Often, the result is a massive shifting of post-production costs from lessors to lessees, as compared to the application of the same lease language in nonMarketable Product Rule jurisdictions.

A careful examination of the jurisprudence reveals that courts applying the Marketable Product Rule have failed to consider some of the far-reaching implications of their doctrine. Specifically, every Marketable Product Rule state has at least one statute declaring the public policy of that jurisdiction to prohibit waste of oil and gas resources. Ironically, as a direct consequence of the Marketable Product Rule's shifting of post-production costs to lessees, natural gas leases

\footnotetext{
* John W. Broomes is a member of Hinkle Law Firm, LLC, in Wichita, Kansas, where he devotes a substantial portion of his practice to oil and gas law. He currently serves as President of the Oil, Gas, and Mineral Law Section of the Kansas Bar Association. He earned his law degree from Washburn University School of Law with a certificate in natural resources law, and his Bachelor of Science in Petroleum Engineering from the University of Texas at Austin.

1. In their comprehensive article on the Marketable Product Rule, Keeling and Gillespie note that of the four states that have clearly adopted a Marketable Product Rule, no two of them articulate the doctrine in the same manner. Byron C. Keeling \& Karolyn King Gillespie, The First Marketable Product Doctrine: Just What Is the "Product"?, 37 ST. MARY's L.J. 1, 79-80 (2005) ("The first marketable product doctrine has thrown oil and gas royalty law into chaos. Four different states have emerged with four different versions of the first marketable product doctrine ....").

2. See Coulter v. Anadarko Petrol. Corp., 292 P.3d 289, 306 (Kan. 2013).
} 
cease to produce in paying quantities earlier in their productive life, resulting in physical waste due to premature abandonment of otherwise recoverable natural gas reserves. Accordingly, the Marketable Product Rule clearly violates the public policy of every state that has adopted it.

\section{DeVelopment of the Marketable Product Rule}

\section{A. Pre-Marketable Product Rule Royalty Jurisprudence}

The Marketable Product Rule has its origins in the interpretation of common oil and gas lease language that provides for gas royalty to be determined "at the well.", Common variations call for royalty based on a share of the "market value" at the well, ${ }^{4}$ or the "proceeds of the sale [of gas] at the mouth of the well." Before the 1960s, courts appeared to have little difficulty applying the typical variants of the royalty clause. Courts consistently concluded that the language meant what it saidroyalty was to be determined "at the well," with lessors routinely bearing the costs of marketing their share of production. ${ }^{6}$ In fact, by the midtwentieth century, the issue had become so well settled that some commentators did not hesitate to declare unequivocally that royalty was to be calculated at the wellhead under all common variations of royalty clauses, even when the lease was silent as to location.?

While royalty was consistently valued at the well, the method of determining royalty varied between clauses, depending on whether the lease called for royalty based on market value, market price, proceeds, or amount realized. When applying a royalty clause based on market value or market price, courts generally defined both terms generically as "the price negotiated by a willing buyer, not obligated to buy, and a willing

3. See, e.g., Rogers v. Westerman Farm Co., 29 P.3d 887, 891 \& n.1 (Colo. 2001); see also Keeling \& Gillespie, supra note 1, at 12-16.

4. See, e.g., TXO Prod. Corp. v. State ex rel. Comm'rs of Land Office, 903 P.2d 259, 260 (Okla. 1994) (as amended on limited grant rehearing, with rehearing being otherwise denied).

5. See, e.g., Gilmore v. Superior Oil Co., 388 P.2d 602, 605 (Kan. 1964).

6. See Joseph T. Sneed, Value of Lessor's Share of Production Where Gas Only Is Produced, 25 TEX. L. REV. 641, 643-44 \& nn.15 \& 17-18 (1947) (collecting cases).

7. See id. at 643-44 \& n.15 (collecting cases); see also Reed v. Hackworth, 287 S.W.2d 912, 913-14 (Ky. 1956) ("[W]here, as here, the lease is silent concerning the place of market and the price, the royalty should be applied to the fair market value of gas at the well."); Scott v. Steinberger, 213 P. 646, 647 (Kan. 1923) (where the lease simply stated that lessor was to be paid "one-eighth of all gas produced and marketed," with no "at the well" language or any other indication of the location at which such gas was to be valued, held that royalty was to be valued at the well, with lessee authorized to deduct transportation costs from downstream sales price); Keeling \& Gillespie, supra note 1 , at $30-31$. 
seller, not obligated to sell, in a free and open market." ${ }^{\text {" }}$ That definition tended to yield an objective standard for valuing royalty that was not necessarily equivalent to the price received by the lessee from the actual sale of production. ${ }^{9}$ By contrast, when the parties wanted to tie royalty to the actual sale of production by the lessee, they used a royalty clause based on the proceeds received, or the amount realized, by the lessee from the actual sale of produced gas. ${ }^{10}$ Like market price and market value, the terms "proceeds" and "amount realized" are generally synonymous. $^{11}$

Regardless of the foregoing variations, unless the royalty clause expressly called for royalty to be valued at some other point, early cases attempted to fix the appropriate value at the well. ${ }^{12}$ When a market existed for gas sold at the wellhead in the general vicinity of the subject well, courts tended to favor the "comparable sales method" for determining market value at the well. Under this method, the market value was simply determined by comparison with other commensurate

8. Howell v. Texaco Inc., 112 P.3d 1154, 1159 (Okla. 2004) (citing Johnson v. Jernigan, 475 P.2d 396, 398 (Okla. 1970)); Sneed, supra note 6, at 645; cf. Decker Coal Co. v. Dep't of Revenue of Montana, 2 P.3d 245, 250 (Mont. 2000) (in the context of coal sales, "[t]he term 'market value' ... means the price that a willing buyer would pay to a willing seller under the market and economic conditions at the time of the sale."). Although determining market value can yield a heated debate, the definition of the term has not been substantially affected by the Marketable Product Rule. See, e.g., Howell, 112 P.3d at 1159 (applying the same definition in 2004, after Oklahoma became a Marketable Product Rule state, as had been used over thirty years earlier in Jernigan). Furthermore, as a general proposition, no meaningful distinction was recognized between market value and its common royalty clause permutation, market price. See Sneed, supra note 6, at 652-54 (stating that there is no difference between the market value and the market price of gas); see also Arkansas Natural Gas Co. v. Sartor, 78 F.2d 924, 927 (5th Cir. 1935) (stating that the terms "market price" and "market value" are interchangeable). But see Shamrock Oil \& Gas Corp. v. Coffee, 140 F.2d 409, 410-11 (5th Cir. 1944) (distinguishing prior Fifth Circuit precedent and attempting to articulate a difference between "market price" and "market value"). The Shamrock case appears to be at odds with the conclusions of other commentators on this point. See, e.g., Atl. Richfield Co. v. Farm Credit Bank of Wichita, 226 F.3d 1138, 1166 \& n.14 (10th Cir. 2000) (quoting 3 Eugene KuntZ, TREATISE ON THE LAW OF OIL AND GaS § 40.4 (1989) (noting the apparent disagreement with the Shamrock case)); Sneed, supra note 6, at 652-53.

9. See Texas Oil \& Gas Corp. v. Vela, 429 S.W.2d 866, 871 (Tex. 1968) (reviewing older cases); see also Shamrock, 140 F.2d 409. See generally Phillips Petroleum Co. v. Bynum, 155 F.2d 196 (5th Cir. 1946) (ignoring actual sales price of gas and looking to objective evidence of market price in surrounding field to determine royalty under clause based on market price at the well).

10. See Vela, 429 S.W.2d at 871.

11. Tana Oil \& Gas Corp. v. Cernosek, 188 S.W.3d 354, 360 (Tex. App. 2006) (collecting cases); see also 8 PATRICK H. MARTIN \& BRUCE M. KRAMER, Williams \& MEYERS OIL AND GAS LAW 45, 87 (2009) (stating that "amount realized" is synonymous with "proceeds").

12. See supra note 7 and accompanying text; Keeling \& Gillespie, supra note 1, at 31 ("The general rule establishing that a lessee could properly calculate its royalty payments at the wellhead was 'a well recognized, basic concept of oil and gas law for many decades ...."' (quoting Scott Lansdown, The Marketable Condition Rule, 44 S. TEX. L. REv. 667, 672 (2003))). 
sales in the relevant geographical area. ${ }^{13}$ When no comparable market existed, or the lessee sold gas off the premises under a proceeds or amount realized royalty clause, courts generally approved the "workback method" of calculating the market value or proceeds at the wellhead. Under the work-back method all costs incurred to move and process the gas from the wellhead to the point of sale were deducted from the actual sales price at such point, thereby arriving at a mathematical determination of value or proceeds at the well. ${ }^{14}$

The work-back method recognizes the marketplace realities associated with the production of any commodity - as the product is transformed from its raw form to a finished product, its value increases; and as that same product is transported from its place of origin or manufacture to its final destination for consumption or other use, its value is likewise enhanced. ${ }^{15}$ That justification for the work-back method has been expressly cited by a number of courts that approve of its application. ${ }^{16}$ Additionally, courts applying the work-back method have specifically relied on "at the well" language in the underlying lease to explain why post-production costs should be deducted. ${ }^{17}$ If royalty is to be determined at the well, then lessor and lessee appropriately share all reasonable costs incurred beyond the wellhead, since both benefit

13. See, e.g., Vela, 429 S.W.2d at 872; Reed v. Hackworth, 287 S.W.2d 912, 914 (Ky. 1956); Bynum, 155 F.2d at 198 ("The question, therefore, is ... whether or not there have been recent, substantial, and comparable sales of like gas...."); Shamrock, 140 F.2d at 411 (articulating comparable sales method without using that label); Wall v. United Gas Pub. Serv. Co., 152 So. 561, 565 (La. 1934); see also Keeling \& Gillespie, supra note 1, at 31-32.

14. See, e.g., Ashland Oil, Inc. v. Phillips Petrol. Co., 554 F.2d 381, 387-88 (10th Cir. 1975); Freeland v. Sun Oil Co., 277 F.2d 154, 159 (5th Cir. 1960); Wall, 152 So. at 564 (noting that the trial court's deduction of post-production costs from sales price to calculate value at the wellhead would have been correct in absence of an actual market at the well); Scott v. Steinberger, 213 P. 646, 64748 (Kan. 1923) (approving the trial court's application of the work-back method to determine value at the well); see also Keeling \& Gillespie, supra note 1, at 32.

15. David E. Pierce, Exploring the Origins of Royalty Disputes, 23 Petroleum Acct. \& Fin. MgMt. J. 72, 77-78 (2004) (describing this phenomena as the "Linear Enhancement of Production Value"). In fact, the work-back method probably overstates the value of production at the wellhead because it subtracts from the sales price only those actual expenses incurred from the well to the point of sale when the actual enhancement of value between those two points exceeds those costs; were it not so, there would be no profit motive to prompt the lessee to incur the added risk and expense to move the production to market. See Keeling \& Gillespie, supra note 1 , at 33 \& n.128 (collecting articles).

16. See Poplar Creek Dev. Co. v. Chesapeake Appalachia, L.L.C., 636 F.3d 235, 244 (6th Cir. 2011); Piney Woods Country Life Sch. v. Shell Oil Co., 726 F.2d 225, 240 (5th Cir. 1984); Merritt v. Sw. Electr. Power Co., 499 So. 2d 210, 213-14 (La. Ct. App. 1986); Schroeder v. Terra Energy, Ltd., 565 N.W.2d 887, 894 (Mich. Ct. App. 1997); Creson v. Amoco Prod. Co., 10 P.3d 853, 858-59 (N.M. Ct. App. 2000).

17. See supra note 16 and accompanying text. 
from the enhanced value created by post-production processing and transportation to a more distant market.

\section{B. Cases Articulating and Adopting the Marketable Product Rule}

Despite the clarity originally perceived by earlier courts in "at the well" language, starting in the 1960s, a number of courts began to express confusion over what "at the well" language meant, and how it should be applied.

\section{Kansas}

In 1964, the Kansas Supreme Court handed down a pair of cases that established what was to ultimately become the Marketable Product Rule as the law of Kansas. ${ }^{18}$ The first of these cases was Gilmore v. Superior Oil Co. ${ }^{19}$ After a number of years venting casinghead gas from oil wells, the lessee in Gilmore installed a compressor on the Gilmore lease and sought to deduct the lessors' share of compression costs from the royalty. ${ }^{20}$ The lessors objected and filed suit. ${ }^{21}$ Where gas was produced and sold, the relevant portion of the lease's royalty clause provided for royalty on "the proceeds of the sale [of gas] at the mouth of the well." 22

18. A few years before Kansas adopted the Marketable Product Rule, the United States Court of Appeals for the District of Columbia Circuit issued a similar ruling in California Co. v. Udall, 296 F.2d 384 (D.C. Cir. 1961). However, the holding in the federal case was predicated on certain federal regulations implementing the Mineral Leasing Act, 30 U.S.C. $\S \S 181-287$ (2012), which required the lessee under a federal oil and gas lease to market the gas. California Co., 296 F.2d at 386-87. The Secretary of the Interior argued that the duty to market imposed by the regulations required the lessee to bear all costs of producing a marketable product, and the court agreed. Id. at 387-88. Since this case turned on federal statutes and regulations, rather than the plain language of the underlying lease, it provides no basis of support for the state cases adopting the Marketable Product Rule.

19. 388 P.2d 602 (Kan. 1964). The second case was Schupbach v. Cont'l Oil Co., 394 P.2d 1 (Kan. 1964). The relevant facts of both Gilmore and Shupbach were essentially the same, as were several of the plaintiffs. See id.; see also supra note 5 and accompanying text. The court concluded as much and held that Gilmore controlled the outcome in Shupbach. Shupbach, 394 P.2d 1. Therefore Shupbach need not be separately discussed in the body of the text. However, one noteworthy distinction between these two cases is that Justice John Fontron, who was appointed to the Kansas Supreme Court after Gilmore was issued, entered a concurring opinion in Shupbach in which he said Gilmore "offends my sence [sic] of logic," and argued that the "at the well" language should be given its plain meaning, with lessors bearing their proportionate share of post-production costs. Id. at 7 (Fontron, J., concurring). Nevertheless, Justice Fontron concurred in Shupbach because Gilmore had already decided the issue. Id.

20. Gilmore, 388 P.2d at 604.

21. Id.

22. Id. at 605 . 
With no meaningful analysis whatsoever, and no explanation of why Kansas would depart from all previous state appellate courts to consider similar language (including prior Kansas precedent), ${ }^{23}$ the Gilmore court summarily concluded that the lease's language was ambiguous, and should thus be construed against the lessee. ${ }^{24}$ The court then promptly turned to implied covenant law (an area of oil and gas law that is largely irrelevant when construing express lease provisions), ${ }^{25}$ and in particular the work of Professor Maurice Merrill, to articulate the essence of the Marketable Product Rule - under the implied covenant to market, the lessee must bear all expenses incurred to place the gas in marketable condition. ${ }^{26}$

Gilmore marked a sharp departure from Kansas law as articulated in Matzen v. Hugoton Production Co. ${ }^{27}$ just a few years earlier. Gilmore attempted to marginalize Matzen's statements regarding deductibility of post-production costs on the alleged basis that the parties therein had "stipulated" to the deductibility of post-production costs. ${ }^{28}$ However, a review of Matzen shows no mention that the parties "stipulated" to anything of the sort; rather, it appears that all of the parties simply recognized the well-established principle that post-production costs were in fact deductible, and they were merely contesting the proper method of applying the deductions to determine royalty. ${ }^{29}$ Indeed, a fair reading of

23. See Matzen v. Hugoton Prod. Co., 321 P.2d 576, 583 (Kan. 1958) (where royalty was to be determined at the wellhead, post-production costs incurred from wellhead to point of sale were deductible); Molter v. Lewis, 134 P.2d 404, 406 (Kan. 1943) ("It is the duty of the lessee to see that the oil is marketed, but this general duty does not mean that the lessee must pay the transportation charge of the less[or]'s share of the oil from the well to some distant place."); Voshell v. Indian Terr. Illum. Oil Co., 19 P.2d 456, 457-58 (Kan. 1933) (where royalty was to be delivered in kind at the well, and no market existed at the well, royalty was to be based on sale at distant location less transportation charges incurred from well to point of sale); Scott v. Steinberger, 213 P. 646, 647-48 (Kan. 1923) (even in absence of "at the well" language, royalty to be valued at the wellhead, not at point of sale). Gilmore did note the Kansas Supreme Court's earlier decision in Matzen; however, the Gilmore court merely observed that, in spite of the fact that all parties had relied on Matzen, that case was irrelevant because the parties had stipulated to the key issue of deductibility of postproduction costs. Gilmore, 388 P.2d at 605. But see infra notes 27-31 and accompanying text.

24. See Gilmore, 388 P.2d at 605. Interestingly, in Waechter v. Amoco Prod. Co., the Kansas Supreme Court looked at materially identical language providing for royalty based on proceeds of a sale "at the well," and concluded that it was clear and unambiguous. 537 P.2d 228, 249 (Kan. 1975). How is it that the same language could be ambiguous in 1964, but clear and unambiguous in 1975? Did the Marketable Product Rule remove the ambiguity? Probably not, inasmuch as Waechter failed to even mention Gilmore, Shupbach, or the Marketable Product Rule.

25. See infra note 113 and accompanying text.

26. See Gilmore, 388 P.2d at 606-07.

27. 321 P.2d 576 (Kan. 1958).

28. Gilmore, 388 P.2d at 605.

29. See Matzen, 321 P.2d at 580-81. 
Matzen makes clear that the Kansas Supreme Court did not merely rely on the parties' general agreement that the lessee could deduct postproduction costs. Instead, the Matzen court broadly declared that in a proceeds-type gas royalty clause:

where, as here, the gas produced is transported by the lessee in its gathering system off the premises and processed and sold, its royalty obligation is determined by deducting from gross proceeds reasonable expenses relating directly to the costs and charges of gathering, processing and marketing the gas. Thus, proceeds from the sale of gas, wherever and however ultimately sold, is the measure of plaintiffs' royalty, less reasonable expenses incurred in its gathering, transporting, processing and marketing. ${ }^{30}$

Contrary to Gilmore's assertion, there is nothing in Matzen that even hints that this sweeping statement was based on any stipulation between the parties. In fact, it would have been ridiculous to make such a broad pronouncement of Kansas law if the court had been relying on a stipulation that it believed was questionable. Rather, this pronouncement was made against the backdrop of a host of other cases from Kansas and elsewhere, and accurately presented the state of the law with respect to deductibility of post-production costs at the time it was written. ${ }^{31}$ Gilmore's attempt to diminish the significance of its departure from Matzen is unconvincing.

The poor analysis and reasoning in Gilmore might be explained as much by the court's reliance on Professor Merrill's scholarship as anything else. Professor Merrill was a staunch advocate of the notion that implied covenants in oil and gas leases are implied in law, rather than implied in fact. ${ }^{32}$ When covenants are implied in law, the text of the lease is largely irrelevant because the parties cannot contract around such covenants. ${ }^{33}$ Thus, the Gilmore court, if proceeding under an implied-inlaw analysis, would have had no need to consider the text of the lease. Nevertheless, the reasoning in Gilmore proceeded from an initial, albeit perfunctory, conclusion that the "proceeds ... at the mouth of the well" language was ambiguous. ${ }^{34}$ In any event, to the extent Gilmore might

30. Id. at 582

31. See generally id. at $581-82$.

32. See Smith v. Amoco Prod. Co., 31 P.3d 255, 268 (Kan. 2001) ("Professor Merrill is the advocate for the implied in law approach." (citing MERRILL, THE LAW RELATING TO COVENANTS IMPLIED IN OIL AND GAS LEASES $\S 220$ (2d ed.1940)).

33. See Mercury Inv. Co. v. F.W. Woolworth Co., 706 P.2d 523, 529 n.14 (Okla. 1985).

34. Gilmore v. Superior Oil Co., 388 P.2d 602, 605. 
have been an initial foray into the world of covenants implied in law, it has been overruled because the Kansas Supreme Court subsequently held, in unequivocal language, that implied covenants under Kansas law are implied in fact, and therefore arise, if at all, after a thorough examination of the express terms of the lease. ${ }^{35}$

In more recent years, Kansas has reaffirmed its adherence to the Marketable Product Rule. In Sternberger v. Marathon Oil Co. ${ }^{36}$ the Kansas Supreme Court stated that the rule in Kansas was the same as that articulated by the Colorado Supreme Court in Garman v. Conoco, Inc. ${ }^{37}$ (discussed infra Part II.B.3):

Once a marketable product is obtained, reasonable costs incurred to transport or enhance the value of the marketable gas may be charged against nonworking interest owners. The lessee has the burden of proving the reasonableness of the costs. Absent a contract providing to the contrary, a nonworking interest owner is not obligated to bear any share of production expense, such as compressing, transporting ${ }_{38}$ and processing, undertaken to transform gas into a marketable product.

Then, in Coulter v. Anadarko Petroleum Corp., ${ }^{39}$ the Kansas Supreme Court noted Colorado's intervening decision in Rogers $v$. Westerman Farm Co. ${ }^{40}$ (discussed infra Part II.B.3), which criticized Sternberger for concluding that gas could be marketable at the well when there was no actual commercial market at that location. ${ }^{41}$ Expressing some continued reverence for Colorado's expansion of the lessee's burdens under the evolving Marketable Product Rule, the Coulter court observed that "[u]nder [Rogers], Sternberger's holding that gas can be in marketable condition at a point at which no market exists may be

35. See Smith, 31 P.3d at 268 ("The Indian Territory court observed in 1941 that it had found no support for Professor Merrill's implied in law doctrine in the adjudicated cases. Sixty years later, based on the briefing here, we share the same observation. We choose to join Oklahoma, Texas, and Montana in holding that the covenants are implied in fact." (citation omitted)). But see Fawcett v. Oil Producers, Inc. of Kan., 306 P.3d 318, 325 (Kan. Ct. App. 2013) (relying on Farrar to perpetuate the notion that Kansas has reversed course and treats the covenants as implied in law); Farrar v. Mobil Oil Corp., 234 P.3d 19, 29-30 (Kan. Ct. App. 2010) (disregarding the clear holding of Smith by trying to limit its broad conclusion that implied covenants are implied in fact). For a more detailed analysis of the flawed reasoning in Farrar, see John W. Broomes et al., Oil, Gas, and Mineral Law, in 2011 KAN. ANN. SURV. 273-75 (Kan. Bar Assoc. 2011).

36. 894 P.2d 788 (Kan. 1995).

37. 886 P.2d 652 (Colo. 1994).

38. Sternberger, 894 P.2d at 800.

39. 292 P.3d 289 (Kan. 2013).

40. 29 P.3d 887 (Colo. 2001).

41. See Coulter, 292 P.3d at 306 (citing Rogers, 29 P.3d at 896-902). 
questionable." ${ }^{42}$ Accordingly, it appears that Kansas may be prepared to follow Colorado's lead in future Marketable Product Rule cases, which, as described in more detail in Part II.B.3, represents one of the most extreme views of the Rule in the United States.

\section{Oklahoma}

For almost thirty years, Kansas was the lone state to embrace the Marketable Product Rule. Then, in 1992, Oklahoma broke from its prior precedent and adopted its own version of the Marketable Product Rule in Wood v. TXO Prod. Corp. ${ }^{43}$ As early as 1936, the state and federal courts in Oklahoma interpreted "at the well" language in gas royalty clauses in accordance with the plain language of that phrase. ${ }^{44}$ In Katschor v. Eason Oil Co. ${ }^{45}$ the lessee processed casinghead gas through a gasoline plant to extract liquid hydrocarbons. ${ }^{46}$ Lessors sued claiming, among other things, that the gasoline content of the gas had been improperly measured, thereby resulting in loss of royalties. ${ }^{47}$

The relevant portion of the lease's royalty clause provided, "The lessee shall pay to lessor for gas produced from any oil well and used by the lessee for the manufacture of gasoline or any other product, as royalty, one-eighth of the market value of such gas." 48 Although the lease was silent regarding the location for determining royalty, the landowners contended that royalty was payable on the value of the gas "at the mouth of the well." "49 Since no market existed at the well, the Oklahoma Supreme Court concluded that the lessors were entitled to establish the market value at the well:

by the only available means, namely, by showing the sale price of the gasoline and the residue gas and deducting from the sum thereof the cost of manufacture of the gas after production, plus depletion of the plant and cost of marketing the gasoline and residue gas.

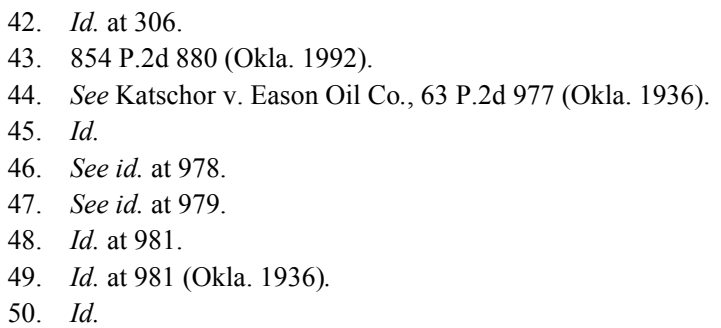


This approval of the work-back method of calculating market value at the well clearly provides for deduction of all post-production costs, including marketing costs and that part of the casinghead gas "deplet[ed]"51 (which, based on the context, presumably means the gas consumed in the manufacturing process). ${ }^{52}$ Nevertheless, the precedential value of this statement was unclear at the time because the landowners did not contend for a more favorable interpretation of the royalty clause.

Four years later, in Cimarron Utilities Co. v. Safranko, the Oklahoma Supreme Court noted with approval that its holding in Katschor regarding the work-back method was in accord with the rule in other jurisdictions. ${ }^{53}$ The court went on to describe the holding in Katschor as establishing that "market value is synonymous with actual value, and may be proved by showing the selling price less the expense of marketing the commodity." ${ }^{, 54}$ Thus, it appeared once again that all reasonable post-production expenses could be deducted to arrive at a proper determination of market value at the well. Moreover, like the royalty provision in Katschor, the lease at issue in Safranko was silent regarding the location for determining value; yet, the parties and the court all seemed to assume that the only logical place for determining value was at the wellhead. ${ }^{55}$ Nevertheless, the statement regarding the Katschor holding was arguably dictum because the real dispute in Safranko was whether the work-back method was the exclusive method for determining market value at the well when gas was sold off the premises, or whether some form of comparable sales method could be employed. $^{56}$

To the extent that the statements from Katschor and Safranko regarding deductibility of post-production costs under Oklahoma law were dicta, the issue appeared to move toward settled law in Harding $v$. Cameron, a federal case out of the Western District of Oklahoma. ${ }^{57}$ The lessee in Harding constructed a compressor station to market low-

51. Id.

52. The more common term for this phenomena is "gas shrinkage," which reflects the volume of gas lost or absorbed in the process of extracting liquids therefrom. See MARTIN \& KRAMER, supra note 11 , at 431 .

53. 101 P.2d 258, 260 (Okla. 1940).

54. Id.

55. See id. at 259-60.

56. See generally id. at 259-61.

57. 220 F. Supp. 466 (W.D. Okla. 1963). 
pressure casinghead gas, ${ }^{58}$ however, the lessee, under a lease providing for royalty based on value or proceeds at the well, ${ }^{59}$ calculated royalty using its own determination of the market value of the gas based, at least in part, on gas purchase contracts the lessee had entered into with other non-operating working interest owners in the relevant leases. ${ }^{60}$ The district court rejected the lessee's methodology, finding instead that no market existed at the wells. ${ }^{61}$ Relying on Katschor, Safranko, and several Kansas cases, the Harding court stated, in no uncertain terms, that:

[t]he rule in Oklahoma fixing the "value," or "market price," of gas at the wellhead and processed by lessee through a compressor plant constructed by it is the gross price which the lessee receives from the purchaser less the actual cost of compression and reasonable depreciation on its compressor plant. ${ }^{62}$

Thus, according to Harding, even compression costs necessary to market gas (a favorite target of Marketable Product Rule cases) were deductible when calculating royalty based on market value at the well. ${ }^{63}$

Things appeared to get even worse for lessors seeking to avoid sharing in post-production costs when the Oklahoma Supreme Court handed down its decision in Johnson v. Jernigan. ${ }^{64}$ In Jernigan, lessors sued over the lessee's deduction of a proportionate share of marketing and transportation costs incurred to move the gas some ten miles to the point of sale. ${ }^{65}$ The royalty clause at issue provided for gas royalty of "the equal one eight [sic] (1/8) of the gross proceeds at the prevailing market rate for all gas sold off the premises." $" 66$ Based on use of the term "gross proceeds" in the royalty clause, the lessors contended that no deductions for marketing and transportation costs were permitted under the lease. ${ }^{67}$

\footnotetext{
58. Id. at $467-68$.

59. Id. at 467 .

60. Id. at $468-70$.

61. Id. at 470 .

62. Id. at 471 .

63. Harding v. Cameron, 220 F. Supp. 466, 471 (W.D. Okla. 1963). See, e.g., Gilmore v. Superior Oil Co., 388 P.2d 602, 604 (Kan. 1964); Shupbach v. Cont'l Oil Co., 394 P.2d 1, 2 (Kan. 1964); Wood v. TXO Prod. Corp., 854 P.2d 880, 880-81 (Okla. 1992).

64. 475 P.2d 396 (Okla. 1970).

65. See id. at 397.

66. Id.

67. Id. at 399 .
} 
In what must have seemed like the death knell for post-production cost battles in Oklahoma, the court concluded that the lessee's obligations essentially ended at the lease boundary. ${ }^{68}$ At least with respect to costs for gathering, transporting, or otherwise piping the gas to the point of sale, even under a clause providing for royalty on "gross proceeds," the lessee was entitled to deduct all costs from the lease to the point of sale. ${ }^{69}$ The Jernigan court defended its holding with a number of cases from other jurisdictions, including a case from the Western District of Louisiana, in which the Louisiana court characterized the deductibility of post-production costs to determine market value at the well as "nothing but common sense and simple justice."

By 1992, however, "simple justice" had become a little too simple for Oklahoma. In Wood v. TXO Prod. Corp., the Oklahoma Supreme Court was presented with the following certified question: "Is an oil and gas lessee/operator who is obligated to pay the lessor ' $3 / 16$ at the market price at the well for the gas sold', entitled to deduct the cost of gas compression from the lessor's royalty interest?"71 Relying heavily on the fact that the compressors were located on the leased premises, and that the gas was sold on the leased premises, the court marginalized Jernigan as only applicable to off-lease transportation costs, and dispensed with Harding in a footnote as applying only to casinghead gas in a work-back analysis. $^{72}$

Having cleared the field of any relevant Oklahoma precedent, the Wood court observed an even split between Texas and Louisiana, on the one hand, which allowed the lessee to deduct the lessor's share of postproduction costs from royalty, and Kansas and Arkansas, on the other, which purportedly did not allow such deductions. ${ }^{73}$ In a 4-to-3 decision, the Wood court adopted a Marketable Product Rule approach. ${ }^{74}$

\footnotetext{
68. See id.

69. Id. If a "gross proceeds" royalty clause allows deduction for all marketing and transportation costs beyond the lease boundaries, what distinction arises when the royalty is based on "net proceeds"? In its conclusion, the court appeared to suggest that charges for the "care and preparation" of gas might be beyond the scope of the holding in Jernigan. See id. at 400 (citing Clark v. Slick Oil Co., 211 P. 496 (Okla. 1922)).

70. Johnson v. Jernigan, 475 P.2d 396, 399 (Okla. 1970) (quoting Hemler v. Union Producing Co., 40 F. Supp. 824, 832 (W.D. La. 1941), aff'd in part, rev'd in part, 134 F.2d 436 (5th Cir. 1943)).

71. Wood v. TXO Prod. Corp., 854 P.2d 880 (Okla. 1992).

72. Id. at $880-82 \&$ n.1.

73. Id. at 881-82.

74. See id. at 883 .
} 
Answering the certified question "in the negative," 75 the Oklahoma Supreme Court said that the implied duty to market includes "the cost of preparing the gas for market,"

Wood suffered from a number of infirmities. First, while the court appeared to begin its analysis by shoe-horning the case into the crack left by Harding and Jernigan with respect to on-lease compression and onlease sales, the certified question was cast in much broader terms, as was the Wood court's answer: "We find that in Oklahoma the lessee's duty to market involves obtaining a marketable product."78 Moreover, the court appeared to go out of its way to both diminish the significance of prior Oklahoma precedent and to present the appearance that other jurisdictions were evenly split on the question, thereby allowing the Oklahoma Supreme Court to write its Marketable Product Rule jurisprudence on a clean slate. In doing so, the Wood court failed to mention that, in addition to Texas and Louisiana, a number of other jurisdictions had already settled the issue in favor of allowing lessees to deduct post-production costs from royalties. ${ }^{79}$ In addition, Wood's reliance on Arkansas as a Marketable Product Rule state was misplaced.

Wood relied on Hanna Oil \& Gas Co. v. Taylor, ${ }^{80}$ in which the Arkansas Supreme Court held that a royalty clause based on "proceeds ... at the well" meant "total proceeds," with no deduction for compression costs, where the lease made no reference to "net" proceeds or otherwise expressly discussed deduction of post-production costs. ${ }^{81}$ Hanna made no pronouncements about implied covenants, lessees' duties, or any other variation on the typical Marketable Product Rule analysis. ${ }^{82}$ Instead, Hanna was simply a case interpreting express lease terms to decide whether the unqualified use of the term "proceeds" meant gross (or total) proceeds, or net proceeds. ${ }^{83}$ Based on the express lease language and the interpretation thereof by the parties' prior

\footnotetext{
75. Id.

76. Id. at 882 .

77. Id. at 883 .

78. Id.

79. See, e.g., Piney Woods Country Life Sch. v. Shell Oil Co., 726 F.2d 225, 240 (5th Cir 1984) (applying Mississippi law); Kretni Dev. Co. v. Consol. Oil Corp., 74 F.2d 497, 499-500 (10th Cir. 1934) (applying Wyoming law); Atl. Richfield Co. v. California, 262 Cal. Rptr. 683, 688 (Cal Ct. App. 1989); Reed v. Hackworth, 287 S.W.2d 912, 914 (Ky. 1956).

80. Wood v. TXO Prod. Corp., 854 P.2d 880, 881-85 (Okla. 1992).

81. Hanna Oil \& Gas Co. v. Taylor, 759 S.W.2d 563, 564-65 (Ark. 1988).

82. See id.

83. Id.
} 
conduct, ${ }^{84}$ the Hanna court concluded that, in this case, "proceeds" meant gross proceeds. ${ }^{85}$ Indeed, despite Oklahoma's enthusiastic desire to count Arkansas among the Marketable Product Rule states, even a recent federal district court case out of Arkansas observed that the issue is far from settled. ${ }^{86}$

Apparently eager to brandish its newly minted Marketable Product Rule, over the next few years the Oklahoma Supreme Court took two more post-production cost cases that could have been decided without any reference to the Marketable Product Rule, and used them to affirm and refine the Rule's place in Oklahoma jurisprudence. ${ }^{87}$ The first of these cases was TXO Prod. Corp. v. State ex rel. Comm'rs of Land Office (hereinafter $C L O),{ }^{88}$ where the dispute centered on a royalty clause that required the lessee:

to deliver or cause to be delivered to the [lessor], without cost into pipelines, a royalty of one-eighth (1/8) part of the oil or gas produced from the leased premises and a one-eighth (1/8) part of all casinghead or drip gas or gasoline or other hydrocarbon substances produced from any well or wells on said premises, or in lieu thereof, pay to lessor the market value thereof, as the Commissioners may elect.

The dispute in $C L O$ centered on whether the lessee could deduct the lessor's share of post-production costs for compression, dehydration, and gathering, ${ }^{90}$ all of which occurred prior to delivery into the purchaser's pipeline. ${ }^{91}$ This royalty provision contained no "at the well" language. ${ }^{92}$ Instead, the provision merely provided for delivery of the royalty share in kind "without cost into the pipelines," or payment of "the market value thereof." "93 The court's analysis of this clause could have begun and

84. See id. at 565 (noting that for over two years, the lessee had paid royalties with no deduction for compression costs).

85. See id. at 564 .

86. See Riedel v. XTO Energy, Inc., 257 F.R.D. 494, 503 (E.D. Ark. 2009); see also Edward B. Poitevent, II, Post-Production Deductions from Royalty, 44 S. TEX. L. REV. 709, 747 (2003) (noting that "Oklahoma is doing its best to pull Arkansas onto the marketable product side by citing its decisions. However, it appears that Arkansas is still reluctant to commit.").

87. See Mittlestaedt v. Santa Fe Minerals, 954 P.2d 1203 (Okla. 1998); TXO Prod. Corp. v. State ex rel. Comm'rs of Land Office, 903 P.2d 259 (Okla. 1994).

88. 903 P.2d 259 (Okla. 1994).

89. Id. at 260 (emphasis added)

90. Id.

91. See id. at 262.

92. See id. at 260.

93. Id. 
ended with the text of the lease itself. The lease called for payment of royalty on "the market value thereof," question, "thereof what?" The answer is easily found in the lease itself a few lines earlier, where the in-kind royalty is defined as a share of the gas delivered "without cost into pipelines." 95 Thus, the CLO court could have simply decided the case on the express terms of the lease's royalty provision by concluding that this particular royalty clause defined the lessor's royalty as the market value of one-eighth of the gas delivered free of cost into the purchaser's pipelines, and because all the disputed costs were incurred prior to delivery into the pipeline, the express terms of the lease prohibited the lessee from deducting such costs from the lessor's royalty.

Rather than decide the case on such a narrow basis, the $C L O$ court made tacit acknowledgment of the express terms of the lease, ${ }^{96}$ but spent the bulk of its opinion deciding the case under the Marketable Product Rule. ${ }^{97}$ In doing so, the court expanded the scope of Oklahoma's Marketable Product Rule to preclude deduction of not only the compression costs excluded in Wood, but also gathering and dehydration costs. $^{98}$

The Oklahoma Supreme Court followed a similar pattern in Mittelstaedt v. Santa Fe Minerals, Inc., ${ }^{99}$ in response to a certified question from the United States Court of Appeals for the Tenth Circuit. The specific question presented by the Tenth Circuit in Mittelstaedt was whether, under the facts of the case, "an oil and gas lessee who is obligated to pay ' $3 / 16$ of the gross proceeds received for the gas sold' [was] entitled to deduct a proportional share of transportation, compression, dehydration, and blending costs from the royalty interest paid to the lessor?"100

As in $C L O$, the lease language was devoid of any specification that royalty was to be valued at the well. ${ }^{101}$ Instead, royalty was simply based

94. TXO Prod. Corp. v. State ex rel. Comm'rs of Land Office, 903 P.2d 259, 260 (Okla. 1994).

95. Id.

96. See id. at 260-61.

97. See id. at $261-63$.

98. Id. at 263 .

99. 954 P.2d 1203 (Okla. 1998).

100. Id. at $1204-05$.

101. Id. The Mittelstaedt opinion also referred to another royalty provision in the lease as follows:

The third clause discussed by the parties provides that the lessee will 'pay lessor for gas produced from any oil well and used off the premises, or for the 
on "the gross proceeds received for the gas sold," regardless of where the sale took place. ${ }^{102}$ Had Oklahoma been writing on a clean slate while interpreting gross proceeds royalty clauses, the Mittelstaedt court might have been able to rely on its old favorite from Arkansas, Hanna Oil \& Gas Co. v. Taylor, for a plain-language interpretation of a gross proceeds provision, and thereby avoided the Marketable Product Rule issue altogether. ${ }^{103}$ However, Oklahoma had not yet discarded the Jernigan case, which held that a gross-proceeds royalty clause still allowed deductions for post-production costs incurred beyond the leased premises. $^{104}$

The Marketable Product Rule proved to be the Mittelstaedt court's tool of choice to fix this conundrum. Rather than correcting Jernigan's error of ignoring the plain text of the lease and simply holding that an unqualified royalty provision calling for royalty on the "gross proceeds received for the gas sold" means what it says-royalty on sales price with no deductions or net-back to the well-Mittelstaedt continued the woeful practice of elevating implied covenants over express lease terms. ${ }^{105}$ In this case, the Marketable Product Rule took over at the lease boundary, where Jernigan's gross-proceeds rule stopped, ${ }^{106}$ and once again required the lessee to bear all costs of producing a "marketable product." 107 Mittelstaedt went even further to conclude that, even after a marketable product was obtained, the lessee could only deduct postproduction costs "when the costs are reasonable, when actual royalty revenues increase in proportion to the costs assessed against the royalty interest, when the costs are associated with transforming an already

manufacture of casing-head gasoline or dry commercial gas, 3/16 of the gross proceeds, at the mouth of the well, received by lessee for the gas . . .."

Id. at 1206 (emphasis added). The court used this provision as a springboard to launch into its application of the implied covenant to market and the Marketable Product Rule; however, that particular lease provision was not the one raised by the Tenth Circuit in its certified question, and was therefore not relevant to the case. See id. All indications are that the applicable royalty language was that quoted by the Tenth Circuit in its certified question. See id. Accordingly, it appears that the Mittelstaedt court decided to pivot - the court decided not to answer the question presented by the Tenth Circuit, but instead answered a different question that was, for some reason, more to its liking.

102. Id. at $1204-05$.

103. 759 S.W.2d 563, 564-65 (Ark. 1988).

104. Johnson v. Jernigan, 475 P.2d 396, 399 (Okla. 1970).

105. Mittelstaedt, 954 P.2d at 1209.

106. Id. at 1206.

107. See id. at 1208 . 
marketable product into an enhanced product, and when the lessee meets its burden of showing these facts." 108

In sum, the pendulum has swung a long way in Oklahoma. This state has gone from one extreme of ignoring the "gross" in "gross proceeds" under Jernigan, to the opposite extreme of reading "at the well" right out of most Oklahoma royalty clauses. Along the way, the Oklahoma courts have extended the Marketable Product Rule to not only preclude deductions for producing a "marketable product," but to also prohibit any deductions thereafter unless the lessee meets a burden of proving a series of facts never addressed or even implied under the relevant lease language.

\section{Colorado}

Shortly after Oklahoma adopted its version of the Marketable Product Rule, Colorado followed suit in Garman v. Conoco, Inc. ${ }^{109}$ Garman involved a certified question from the federal district court in Colorado:

Under Colorado law, is the owner of an overriding royalty interest in gas production required to bear a proportionate share of postproduction costs, such as processing, transportation, and compression, when the assignment creating the overriding royalty interest is silent as to how post-production costs are to be borne?

The Colorado Supreme Court immediately proceeded to an analysis under implied covenant law with little discussion of the disagreement among courts and scholars as to whether implied covenants should even apply to overriding royalty interests. ${ }^{111}$ Next, although Colorado has

\footnotetext{
108. Id. at 1210 .

109. 886 P.2d 652 (Colo. 1994).

110. Id. at 653 .

111. See id. at 654; see also XAE Corp. v. SMR Prop. Mgmt. Co., 968 P.2d 1201, 1204 07 (Okla. 1998) (summarizing the controversy over application of implied covenants to overriding royalty interests, and ultimately rejecting the application of implied covenants to the overriding royalty interests at issue in the case). As XAE Corp. explained, implied covenants ordinarily arise out of oil and gas leases, rather than instruments (like assignments) used to create overriding royalty interests. See XAE Corp., 968 P.2d at 1204. The concept is succinctly explained by Williams and Meyers as follows:

The owner of an overriding royalty is not entitled to the benefit of the covenants of the base lease, express or implied, in the absence of an express provision in the instrument creating the overriding royalty. The benefits of such express and implied covenants of the lease touch and concern the lessor's estate and burdens of such covenants touch and concern the lessee's estate.
} 
traditionally held that covenants implied in oil and gas leases are implied in fact, which requires analysis of the lease language to determine whether an implied covenant is even applicable, the majority in Garman limited its legal analysis to general principles of implied covenant law with no regard for the language of the disputed instrument. ${ }^{112}$

The Garman court began its analysis by "relying on the basic proposition that every oil and gas lease contains an implied covenant to market ...."

The assignment, either in whole or in part, of the burdened estate will not permit enforcement of the covenants which burden the assigned estate by a person other than the lessor or claimants though him of a portion or all of the benefitted estate.

Id. (quoting WiLliams \& MEYERS, OIL AND GAS LAW § 420 (1981)).

112. See infra note 113 and accompanying text. See generally Garman, 886 P.2d at 656-60.

113. Id. at 654. This (and similar statements from other jurisdictions) amounts to a gross misstatement of law. Colorado first recognized implied covenants in oil and gas leases in Mountain States in 1942. Mountain States Oil Corp. v. Sandoval, 125 P.2d 964 (Colo. 1942). Therein, the Colorado Supreme Court observed that "[t]he basis of [implied covenants] in each instance is the presumed intention of the parties. 'Whatever is implied in a contract is as effectual as what is expressed. Implication is but another name for intention, and if it arises from the language of the contract when considered in its entirety, and is not gathered from the mere expectations of one or both of the parties, it is controlling." Mountain States, 125 P.2d at 967 (quoting Brewster v. Lanyon Zinc Co., 140 F. 801, 809 (8th Cir. 1905)). This fits the classic definition of a covenant implied in fact. See David E. Pierce, The Renaissance of Law in the Law of Oil and Gas: The Contract Dimension, 42 WASHBuRn L.J. 909, 924 (2004). Covenants implied in fact can always be negated by the express terms of the agreement because implied covenants are based on presumed intent, which is easily rebutted by express contract language. Thus, the unequivocal statement that "every oil and gas lease contains an implied covenant to market" is demonstrably incorrect. Garman, 886 P.2d at 654 . Indeed, the only absolute statement one can accurately make regarding covenants implied in fact is that not every oil and gas lease contains an implied covenant to market. Instead, only those oil and gas leases that fail to expressly address the matters normally covered by the implied covenant to market might be found to contain an implied covenant to market.

To be sure, there are some covenants that are implied in every contract, but such covenants are implied-in-law. See, e.g., Amoco Oil Co. v. Ervin, 908 P.2d 493, 499 (Colo. 1995) (holding that the covenant of good faith and fair dealing is "implied at law" in every contract and cannot be varied by express contract language to the contrary); see also Pierce, supra, at 911-24 (providing detailed analysis of implied-in-law and implied-in-fact covenants). Unfortunately, it appears that the distinction between covenants implied in fact and those implied in law has been lost on Marketable Product Rule courts. Indeed, the Garman court summarized its holding as, "absent an assignment provision to the contrary, overriding royalty interest owners are not obligated to bear any share of post-production expenses, such as compressing, transporting and processing, undertaken to transform raw gas produced at the surface into a marketable product." Garman, 886 P.2d at 661 (emphasis added). The highlighted language is completely at odds with the notion that every oil and gas lease (or, in this case, every instrument creating an overriding royalty interest) contains an implied covenant to market. In fact, it means quite the opposite because if the covenant can be negated by express lease language, it is implied in fact and arises only by implication from an examination of the lease's terms. Similarly, in the concurring opinion in Garman, Justice Erickson made the following irreconcilable statements: "Oil and gas leases in Colorado uniformly contain an implied covenant to market the gas produced by the lessee .... The parties to an oil and gas lease may, by express agreement in the lease, limit the covenants implied in the lease." Garman, 886 P.2d 
jurisdictions that had grappled with deduction of post-production costs, observing that Texas and Louisiana allowed such deductions for costs incurred beyond the wellhead, but that Kansas and Oklahoma had adopted some form of the Marketable Product Rule. ${ }^{114}$ Garman also tried to place Arkansas and North Dakota in the Marketable Product Rule camp, although Arkansas is still questionable, ${ }^{115}$ and North Dakota has since rejected the notion. ${ }^{116}$ The Garman court quickly concluded that, under Colorado's version of the Marketable Product Rule, "absent an assignment provision to the contrary, overriding royalty interest owners are not obligated to bear any share of post-production expenses, such as compressing, transporting and processing, undertaken to transform raw gas produced at the surface into a marketable product." "117 Further, once a marketable product has been obtained, only those costs which a lessee can prove actually enhance the product's value, are reasonable, and actually increase royalty revenues in proportion with such costs, may be deducted from the overriding royalty owner's share of revenue. ${ }^{118}$

Garman brings into focus one of the principal problems of the Marketable Product Rule: it takes a contract interpretation issue and converts it into an inquiry about the plaintiffs' status. The Garman majority failed to even consider the contract language, but rather made the case about the plaintiffs' status as royalty owners. ${ }^{119}$ Finding that a royalty owner is a royalty owner (whether a lessor or the holder of an overriding royalty), ${ }^{120}$ the application of the implied covenant to market in a vacuum automatically yielded a Marketable Product Rule solution. To be sure, it can be enticing for overworked jurists to avoid the tedious work of interpreting complex agreements by crafting rules of law that make that inquiry unnecessary, but is this really fair to those who have staked their livelihood on the text of those contracts?

\footnotetext{
at 663,664 (Erickson, J., concurring). The first statement can be true only if the covenant to market is implied in law. The second is true only if the covenant is implied in fact. In either event, they are mutually exclusive. Sadly, neither the majority opinion nor the concurrence recognized this rudimentary error. Consequently, every case that relies on Garman's misconception regarding implied covenants should be heavily scrutinized because it is based on a fundamental misunderstanding of the distinctions between covenants implied in law and those implied in fact.

114. See Garman, 886 P.2d at 657-58.

115. See id. at 658 .

116. See Bice v. Petro-Hunt, L.L.C., 768 N.W.2d 496 (N.D. 2009).

117. Garman, 886 P.2d at 661 .

118. See id.

119. See id

120. But see supra note 111 and accompanying text.
} 
A few years after the Garman decision, the Colorado Supreme Court once again took up disputes over deduction of post-production costs in the widely panned Rogers $v$. Westerman Farm Co. ${ }^{121}$ In Rogers, a host of royalty and overriding royalty owners sued their lessees in a twopronged attack grounded in Colorado's Marketable Product Rule. First, the plaintiffs took the typical approach of attacking the deductibility of post-production costs for downstream sales under the Marketable Product Rule. ${ }^{122}$ Second, the plaintiffs asserted that any sales that occurred at the wellhead were invalid for purposes of determining their royalties because the Marketable Product Rule prohibited the sale of gas until it was in a marketable condition, and they alleged that none of the gas attributable to the plaintiffs' wells was in marketable condition at the wellhead. ${ }^{123}$

While noting that there were four basic variations of royalty clauses at issue in Rogers,${ }^{124}$ all of which based royalty on some combination of market value or proceeds from sales "at the well" or "at the mouth of the well," the court concluded that the leases were silent with regard to allocation of post-production costs. ${ }^{125}$ Relying then on the fallacy that every oil and gas lease contains an implied covenant to market, ${ }^{126}$ the court proceeded to expand the scope of the Marketable Product Rule that it had crafted in Garman. Rejecting the Colorado Court of Appeals' conclusion that gas is marketable if someone will buy it, ${ }^{127}$ the state supreme court extended its Marketable Product Rule to hold that not only must a lessee bear all costs to place raw gas in pipeline quality, but the lessee must also bear all costs to deliver such marketable gas to the location of an actual commercial marketplace. ${ }^{128}$ Once the lessee meets those two requirements, it can then deduct reasonable post-production costs to further enhance the gas or transport it to a more distant market. ${ }^{129}$

\footnotetext{
121. 29 P.3d 887 (Colo. 2001).

122. Id. at $893-94$.

123. Id. at 893. Plaintiffs also alleged that the wellhead sales were not arms-length transactions because the purchasers were "closely linked" to the lessees; consequently, those sales were likewise invalid under the Marketable Product Rule. See id.

124. Id. at $891 \mathrm{n} .1$.

125. See id. at 896-97.

126. Id. at 902 . See supra note 113 and accompanying text.

127. See Rogers v. Westerman Farm Co., 29 P.3d 887, 895-96 (Colo. 2001) (rejecting the court of appeals' conclusion that "the fact that the gas was actually sold at the well showed that it was marketable there").

128. Id. at 906 .

129. Id.
} 
Rogers represents many extremes in oil and gas contract interpretation. The Colorado Supreme Court seems to set the stage by first impugning the lessees because their standard royalty clauses provide "an initial misleading appearance that the lease language provides for allocation of costs." $" 130$ The court further maligns the lessees by analogizing them with insurance companies based on an oil and gas treatise written almost a hundred years earlier. ${ }^{131}$ Having thus established the moral basis for what it is about to do, the court proceeds to lay waste to a number of legal precepts of oil and gas contract interpretation that were, by and large, well-established at the time the leases were entered into. First, the court ignores long-established Colorado precedent that implied covenants are implied in fact (which requires examination of the individual lease terms), ${ }^{132}$ by simply grouping all the applicable royalty clauses into four groups and then ignoring the distinctions that exist even among those groups. ${ }^{133}$ Instead, the court concludes that the implied covenant to market applies to every lease (which, by definition, means that the covenant is implied in law,

130. Id. at 897 (emphasis added).

131. Id. at 902 (citing Ladd v. Upham, 58 S.W.2d 1037, 1039 (Tex. Civ. App. 1933)).

132. See Mountain States Oil Corp. v. Sandoval, 125 P.2d 964, 967 (Colo. 1942); see also supra note 113 and accompanying text.

133. See Rogers, 29 P.3d at $897-98$. While the four royalty clause variants expressed the means for determining royalty with varying levels of clarity, $i d$. at $891 \mathrm{n} .1$, the Type 1 clause was certainly of sufficient clarity to merit different treatment if the court were truly trying to apply the language as written. The Type 1 clause read as follows:

[L]essee shall pay to lessor a sum equal to one-eighth (1/8th) of the gross proceeds received from the sale of such produced substances where the same is sold at the mouth of the well or, if not sold at the mouth of the well, then one-eighth $(1 / 8$ th) of the market value thereof at the mouth of the well, but in no event more than one-eighths of the actual amount received by the lessee for the sale thereof.

$I d$. This clause very specifically provided for two different scenarios. First, if gas was actually sold at the well, then royalty was based on the gross proceeds received by the lessee. The use of the term "gross proceeds," rather than "net proceeds," indicates that no deductions were to be taken, which is consistent with a sale at the well where there would be no post-production costs incurred from the wellhead to some downstream point of sale. Id. However, in the event of a downstream sale, this clause quite clearly provides that "if not sold at the mouth of the well," royalty is based on the market value at the well. Id. In both instances, royalty is based on the value of the gas as it comes out of the ground. The "market value ... at the mouth of the well" prong of the Type 1 royalty clause anchors royalty to the wellhead despite a downstream sale, while the "gross proceeds" prong removes the uncertainty in determining market value by basing royalty on the actual proceeds of any sales that occur at the wellhead. Id. This language is clear, requires no imagination to apply, and provides no gap for the alchemy of the Marketable Product Rule to intervene. As Rogers demonstrates, application of the Marketable Product Rule to the Type 1 clause collapses the two alternative methods for calculating royalty that are expressly set forth therein into a single, courtimposed royalty calculation based on value at some downstream market where the gas meets the court's definition of marketability. 
thus overruling Colorado precedent), ${ }^{134}$ thereby dictating a uniform result regardless of the express terms of the lease. ${ }^{135}$ Second, the court ignores express "at the well" language in the royalty clauses, rendering those words utterly meaningless, thus violating the canon of construction against rendering contract terms as mere surplusage. ${ }^{136}$ Third, in the face of a stinging rebuke by its Marketable Product Rule sister court from Oklahoma for Colorado's unprincipled application of implied covenant law to overriding royalty interests, ${ }^{137}$ the Rogers court stubbornly reaffirmed its holding from Garman that a royalty interest is a royalty interest. ${ }^{138}$ Thus, despite the fact that implied covenants arise out of the oil and gas lease in favor of the lessor, not from an assignment or reservation of an overriding royalty interest, under Colorado's version of the Marketable Product Rule all royalty owners deserve the same benevolent treatment, whether they are lessors, former lessees, or even sophisticated investors. ${ }^{139}$ Through Garman and Rogers, Colorado has probably pushed the Marketable Product Rule to its most extreme interpretation within the United States.

\section{West Virginia}

In the realm of the post-production cost deductibility wars, West Virginia seems to take a rather unique approach. While most commentators include West Virginia with the Marketable Product Rule states, ${ }^{140}$ West Virginia has actually achieved a Marketable Product Rule

134. See supra notes 124-26 and accompanying text. Curiously, the Rogers court also states that "the implied covenant to market controls the allocation of costs under circumstances where lease language fails to address cost allocation." Rogers v. Westerman Farm Co., 29 P.3d 887, 900 (Colo. 2001). That sounds a lot like a covenant implied in fact, except that the court continues to repeat its statement that the implied covenant to market is implied in every lease. Id. at 902, 903. To the extent those two principles can be reconciled, at a practical level it appears to mean that the implied covenant to market represents the default rule, which can theoretically be negated by express lease language, although we have yet to see any lease provisions that can actually withstand the nullification power of Colorado's Marketable Product Rule.

135. See generally Rogers, 29 P.3d at 896-99.

136. See id.; see also infra note 163 and accompanying text

137. Id. at 902 n.16 (noting disagreement with Oklahoma's XAE Corp. v. SMR Prop. Mgmt. Co., 968 P.2d 1201 (Okla. 1998)).

138. Id. at 902 .

139. Id.

140. See, e.g., Keeling \& Gillespie, supra note 1, at 5; Lindsey Scheel, Oil and Gas Law-Rent or Royalties: North Dakota Joins the Majority of States in Adopting the "At the Well" Rule for Calculating Royalties on Oil and Gas Leases Bice v. Petro-Hunt, L.L.C., 2009 Nd 124, 768 N.W.2d 496, 85 N.D. L. REV. 919, 927 (2009); see Karen E. Kahle \& Denielle M. Stritch, Grouping the Marcellus Payout: Use of Class Actions in Royalty Litigation Concerning Post-Production Cost 
result that seems to arise more from an unwillingness to accept the realities of deregulation in the natural gas market than from implied covenant law. ${ }^{141}$ The West Virginia approach can be traced through two cases. In Wellman v. Energy Res., Inc., ${ }^{142}$ a lessor attacked deductions of post-production expenses under a royalty clause that provided for royalty on "one-eighth $(1 / 8)$ of the proceeds from the sale of gas as such at the mouth of the well." 143 Although the lessee disposed of the gas through a downstream sale for $\$ 2.22$ per MCF, it calculated royalty based on a sales price of $\$ 0.87$ per MCF, alleging that the difference was due to unspecified and unsupported post-production costs. ${ }^{144}$

Rather than begin with an analysis of the lease provision, the Wellman court turned first to a 1951 West Virginia oil and gas treatise that stated:

From the very beginning of the oil and gas industry it has been the practice to compensate the landowner by selling the oil by running it to a common carrier and paying him [the landowner] one-eighth of the sale price received. This practice has, in recent years, been extended to the situations where gas is found. The one-eighth received is commonly referred to as the landowner's royalty.

Next, the court makes a brief review of the ongoing Marketable Product Rule dispute between Texas and Louisiana, on the one hand, and Colorado, Oklahoma, and Kansas, on the other. ${ }^{146}$ Voicing some approval of the Marketable Product Rule, ${ }^{147}$ and noting that, like the other Marketable Product Rule jurisdictions, West Virginia recognizes an implied covenant to market, ${ }^{148}$ Wellman seemed to be plotting a course to

Deductions, 88 N.D. L. REV. 699, 724 (2012); Rachel M. Kirk, Variations in the MarketableProduct Rule from State to State, 60 OKLA. L. REV. 769, 799-800 (2007); David E. Pierce, Royalty Jurisprudence: A Tale of Two States, 49 WASHBURN L.J. 347, 373 n.144 (2010).

141. See Pierce, supra note 140, at 367-68.

142. 557 S.E.2d 254 (W. Va. 2001).

143. Id. at 258 .

144. See id. at $263,265$.

145. Id. at 263 (quoting Robert Donley, The LaW of CoAl, Oil AND Gas IN West Virginia AND VIRGINIA § $104(1951)$ ).

146. See id. at 264-65.

147. See id. at 265 .

148. See id. The significance of this observation is unclear. Virtually all oil and gas producing states, including Texas and Louisiana, recognize the implied covenant to market. See Stirman v. Exxon Corp., 280 F.3d 554, 564-65 (5th Cir. 2002) (listing most of the oil- and gas-producing states as recognizing an implied covenant to market); See also Kirk, supra note 140, at 774 (stating that it is not the recognition of the covenant, but its application that distinguishes Marketable Product Rule 
add West Virginia to the list of Marketable Product Rule states, concluding, "if an oil and gas lease provides for a royalty based on proceeds received by the lessee, unless the lease provides otherwise, the lessee must bear all costs incurred in exploring for, producing, marketing, and transporting the product to the point of sale." the "point of sale" language would be a new twist on the Rule, the rest of the quote sounds a lot like a Marketable Product Rule formulation.

However, the legal foundation for West Virginia's approach to address the deductibility of post-production costs became a lot less clear after Estate of Tawney v. Columbia Natural Res., L.L.C. ${ }^{150}$ Tawney was a royalty-owner class action involving some 8,000 plaintiffs, and included over 1,300 oil and gas leases that provided for royalty using some variation of "at the wellhead" language. ${ }^{151}$ As in Wellman, where the lessee calculated royalty on a price far below the actual sale price without providing any evidence of deductible costs, Tawney was also predicated on bad facts in that this lessee deducted post-production costs without even disclosing the deductions on the lessors' accounting statements. ${ }^{152}$

As in Wellman, the Tawney court briefly reviewed the ongoing skirmish between other states regarding the Marketable Product Rule, but declined to formally take sides, choosing instead to rely on the trail previously blazed in Wellman. ${ }^{153}$ Reaffirming its reliance on the 1951 treatise, and quoting extensively from Wellman, the West Virginia Supreme Court picked up where it left off in Wellman and concluded that

states from other jurisdictions; in a non-Marketable Product Rule state, the implied covenant to market does not impose a duty to market for free).

149. Wellman, 557 S.E.2d at 265.

150. 633 S.E.2d 22 (W. Va. 2006)

151. Id. at 25. By allowing royalty-owner class actions like this, the courts have helped create the very circumstances that often motivate them to craft unprincipled "one-size-fits-all" solutions. Oil and gas leases are just contracts. Basic contract law teaches us that the first step in interpreting a contract is to analyze the language contained therein. Only after that examination reveals an ambiguity do we consider rules of construction, extrinsic evidence, and, in the oil and gas context, implied covenants. However, when we allow contract cases to proceed as class actions, judges are faced with the daunting task of examining hundreds, even thousands, of contracts in a single case. Human nature being what it is, judges are tempted to look for shortcuts to avoid such a burdensome task. The methodology applied by Marketable Product Rule courts represents such a shortcut. Cases like Rogers and Tawney take thousands of different contracts, place them in a handful of groups, and then, with a paragraph or so, collapse all the groups into a single analysis in which implied covenants and generalizations replace rigorous contract examination. The result is sweeping public policy decisions manifested as rules of law that override the terms of thousands upon thousands of individually negotiated agreements.

152. See id. at 25 .

153. See id. at $26-27$. 
none of the various formulations of "at the wellhead" language presented in the 1,300-plus leases was sufficient to allocate post-production costs. ${ }^{154}$ Consequently, none of the defendant lessee's leases allowed it to deduct post-production costs from the lessors' royalties. ${ }^{155}$

In both Wellman and Tawney, we see West Virginia's unique approach to the deductibility of post-production costs. First, and most obvious, West Virginia's formulation is tied directly to the point of sale. Neither Wellman nor Tawney appeared to put any qualifications on the point-of-sale aspect of the West Virginia rule, so presumably it is irrelevant whether the point of sale occurs at the wellhead or the burner tip; in either event, the lessor would receive a cost-free royalty on the sale proceeds. ${ }^{156}$ The more intriguing aspect of the West Virginia rule is the manner in which it clings to pre-deregulation marketing practices. As Professor David Pierce notes in his article, Royalty Jurisprudence: A Tale of Two States, the treatise on which the West Virginia Supreme Court relied so heavily for its pronouncement that West Virginia lessors traditionally received a cost-free royalty out of the sale price was written in 1951 in the midst of the regulatory scheme imposed under the Natural Gas Act of 1938, in which almost all sales of natural gas occurred at the wellhead. ${ }^{157}$ Similarly, the Tawney court impugned the lessee, stating, "although some of the leases below were executed several decades ago, apparently [the lessee] did not begin deducting post-production costs from the lessors' royalty payments until about 1993."158 As Pierce observes, this change in the lessee's accounting practices corresponded with the end of the regulatory scheme in $1993 .{ }^{159}$ Accordingly, it seems that the West Virginia court failed to consider the effects of regulation and deregulation on the sales and marketing practices of lessees,

\footnotetext{
154. See id. at 28.

155. See id. at 30 .

156. Both Tawney and Wellman included brief statements about the lessor's duty to render the gas in marketable condition. See Tawney, 633 S.E.2d at 27; see also Wellman v. Energy Res., Inc., 557 S.E.2d 254, 265 (W. Va. 2001). However, it is difficult to determine whether West Virginia would rely on that language to suggest that a wellhead sale was improper because the gas was not in marketable condition. If West Virginia intended to leave that possibility open, it would have been best to include that caveat in its formulation of the holdings in Wellman and Tawney. The court's failure to do so strongly implies that the true focus will be the point of sale, not marketability. But see W.W. McDonald Land Co. v. EQT Prod. Co., 983 F. Supp. 2d 790, $799-802$ (S.D.W. Va. 2014) (expressly rejecting statements in Tawney and Wellman regarding point of sale and holding instead that the lessee's duty to market is satisfied upon delivery to an actual market).

157. Pierce, supra note 140, at 367-68.

158. Tawney, 633 S.E.2d at 28.

159. Pierce, supra note 140 , at 368.
} 
assuming instead that historical practices from a bygone era of robust regulation represent industry norms even in an unregulated market. In any event, West Virginia is probably counted among Marketable Product Rule jurisdictions more because it has achieved something in the nature of a Marketable Product Rule result, than because it applies a Marketable Product Rule analysis.

\section{Problems Created by the Marketable Product Rule}

Aside from the public policy problems discussed infra, the Marketable Product Rule suffers from a number of other infirmities. First, the Marketable Product Rule results in a judicially directed wealth transfer from lessees to lessors that contradicts the bargained-for exchange struck by the parties, as expounded upon by years of court precedent. ${ }^{160}$ It seems counter-intuitive that courts would ignore explicit "at the well" language, finding it ambiguous, but nevertheless conclude that the lease implicitly calls for royalty to be valued at some point further down the innumerable miles of pipelines, meters, and facilities downstream of the wellhead, at which point the product becomes marketable for royalty calculation purposes. As for those jurisdictions like Colorado and West Virginia, which have "solved" the resulting location problem by grafting in their own determinations as to marketable location or point of sale, those decisions are completely unmoored from the text of the underlying leases. On the contrary, the lease language should be the beginning point for any exercise in contract interpretation. ${ }^{161}$ Indeed, while Marketable Product Rule courts often begin by concluding that "at the well" language is ambiguous (or even "silent") ${ }^{162}$ with respect to allocation of post-production costs, those courts universally fail to offer any suggestion as to why the phrase "at the well" is included in the royalty clause. This violates the cardinal rule of construction that courts must strive to give meaning to every term in the lease, rendering none as mere surplusage. ${ }^{163}$ Under the Marketable

160. See Keeling \& Gillespie, supra note 1, at 30-31.

161. See supra note 113 and accompanying text.

162. See, e.g., Rogers v. Westerman Farm Co., 29 P.3d 887, 902 (Colo. 2001).

163. 17A C.J.S. Contracts $\S 400$ (2014) ("construction rendering a provision, term, or part meaningless, superfluous, surplusage, useless, inexplicable, or nugatory should be avoided.”); id. $\S$ 418; 11 WILLISTON ON CONTRACTS § 32:1 (4th ed. 2012) ("Individual clauses and particular words of the agreement, and all parts of the writing and every word of it, will, if possible, be given effect."); see also Pierce, supra note 140, at 361-64 (observing that Marketable Product Rule courts "negate" the meaning and effect of "at the well" language in royalty clauses). 
Product Rule, "at the well" is rendered meaningless surplusage, with courts essentially re-writing the lease to provide for royalty based on "market value at the location where the gas achieves pipeline quality." The Colorado Supreme Court demonstrates a striking example of this problem in Rogers where, after noting the obvious problem with rendering "at the well" meaningless, the court brazenly proceeds to do precisely that. ${ }^{165}$

Perhaps more troubling, the Marketable Product Rule essentially forces the lessee to be the guarantor of the physical properties of any natural gas discovered on the leased premises by requiring the lessee to bear the risk that gas of lesser quality may be located thereunder, as compared to better gas that more closely matches the specifications for pipeline quality. This idea may be best illustrated through a comparison with hard-rock mining. If a miner discovers silver on one tract of land and gold on another, no one expects the miner to pay the silver royalty owner as if his land produced gold. Instead, the law implicitly recognizes that the bounties of nature are not evenly distributed, and that each mineral owner is entitled to the benefits of those valuable minerals, if any, discovered on his property. As natural and unremarkable as that may sound, the world gets turned on its head when the Marketable Product Rule is applied: landowners fortunate enough to have under their property large volumes of low-pressure, sour gas, with high levels of moisture and carbon dioxide, are to be paid as if they had the better fortune of being underlain with high-pressure, sweet gas, containing no other contaminants, with the lessee bearing the expense of correcting the disparity. ${ }^{166}$ Just as a hard-rock miner is not expected to guarantee that every mineral deposit is gold, the oil and gas lessee should not have to warrant that all gas he discovers will be pipeline quality when it comes out of the ground. Instead, lessor and lessee should equally bear the risk in the random distributions of gas quality found in nature. ${ }^{167}$

\footnotetext{
164. Rogers, 29 P.3d at 902.
}

165. Rogers, 29 P.3d at 906 (noting Professor Anderson's efforts to apply the Marketable Product Rule while retaining some meaning for "at the well" language, and then rejecting same.).

166. Cf. Richardson v. Homestake Min. Co., 322 F.2d 329 (10th Cir. 1963) (stating that in the hard-rock mining context, the lessee is entitled to deduct from lessor's royalty a proportionate share of post-production costs incurred to process ore).

167. See Pierce, supra note 140 , at 375 ("[W] geology? Is it the lessee's fault the leased land is located miles from the nearest interstate pipeline? Is it the lessee's fault that the gas that is discovered is of low pressure, of low British thermal units (Btu), or low-volume gas with contaminants such as water, hydrogen sulphide, and carbon dioxide? In each case, the parties must deal with the geological facts associated with the leased land. Nobody is at fault; nobody is responsible for the situation."). 


\section{The Public Policy Against Waste}

\section{A. Conservation Statutes}

Like most oil and gas producing states, each and every Marketable Product Rule jurisdiction has at least one statute proclaiming that the public policy of that state prohibits waste of oil and gas resources. The Kansas legislature has declared that " $[\mathrm{t}]$ he production of natural gas in the state of Kansas in such manner and under such conditions and for such purposes as to constitute waste is hereby prohibited."168 Oklahoma's statute proscribing waste of natural gas tracks the Kansas version almost word-for-word. ${ }^{169}$ The West Virginia legislature has staked out its position with even more sweeping language, stating:

It is hereby declared to be the public policy of this state and in the public interest to:

(1) Foster, encourage and promote exploration for and development, production, utilization and conservation of oil and gas resources;

(2) Prohibit waste of oil and gas resources ... ; [and]

(3) Encourage the maximum recovery of oil and gas ... ${ }^{170}$

Finally, like West Virginia, the Colorado legislature has expressly recognized the public, as well as the private, interest in preventing waste, stating, "It is declared to be in the public interest to ... [p]rotect the public and private interests against waste in the production and utilization of oil and gas."

168. KAN. StAT. ANN. § 55-701 (2012); see also id. § 55-601 (prohibiting waste of crude oil and petroleum).

169. See OKLA. Stat. ANN. tit. 52, § 236 (West 2001) ("The production of natural gas in the State of Oklahoma, in such manner, and under such conditions as to constitute waste, shall be unlawful"); see also id. $\S 271$ (prohibiting waste of crude oil and petroleum); id. § 86.2 ("The production of oil in the State of Oklahoma in such manner and under such conditions as to constitute waste as in this act defined is hereby prohibited"); id. $\S 86.3$ ("The production of gas in the State of Oklahoma in such manner and under such conditions as to constitute waste as in this act defined is hereby prohibited").

170. W. VA. CODE ANN. § 22C-9-1(a) (West Supp. 2013); see also id. § 22C-9-6 ("Waste of oil or gas is hereby prohibited"); see also id. $\S 22 \mathrm{C}-8-1$ (declaring public policy to maximize recovery of coal and natural gas where both underlie same lands).

171. Colo. Rev. Stat. AnN. § 34-60-102(1)(a)(II) (West Supp. 2013); see also id. § 34-60-107 ("The waste of oil and gas in the state of Colorado is prohibited by this article"). 
Indeed, there is a great public interest, both for a given state and for our nation, in responsibly maximizing the production of oil and gas resources. ${ }^{172}$ Energy is the lifeblood of our economy, indispensible for manufacturing and transporting goods; without it, store shelves would be empty because there would be no fuel to move goods to market, and our economy would grind to a halt as people could not commute to work. Severance taxes on hydrocarbon production send much needed revenues into the coffers of producing states, while drilling and production operations contribute jobs to an ailing economy. The more America's energy needs can be met domestically, the less dependent our nation becomes on foreign energy sources, which are often found in areas of the world that are politically unstable or not otherwise favorably disposed toward the United States. Finally, natural gas, which is the focus of this paper, is an abundant, comparatively environmentally friendly energy source, having a little over half the carbon emissions per unit of energy as crude oil, and an even smaller fraction when compared to coal. ${ }^{173}$ For all these reasons, and many others, the legislatures of these Marketable Product Rule states have correctly observed that it is in the public interest to prevent waste, and maximize production, of oil and gas resources.

\section{B. What is Waste?}

In defining "waste" for their statutory purposes, each of these states has embraced an expansive view of the concept, combining the traditional view of "physical waste, as the term is generally understood in the oil and gas industry," "174 with a multitude of additional descriptions to rake in economic waste, underground waste, surface waste, and an array of other permutations. ${ }^{175}$ Interestingly, it is not the expansive concept of

172. See generally Coastal Oil \& Gas Corp. v. Garza Energy Trust, 268 S.W.3d 1, 26-29 (Tex. 2008) (Willett, J., concurring).

173. See Dr. William C.G. Burns, A Voice for the Fish? Climate Change Litigation and Potential Causes of Action for Impacts Under the United Nations Fish Stocks Agreement, 48 SANTA Clara L. ReV. 605, 624 (2008); Arnold W. Reitze, Jr., Federal Control of Carbon Dioxide Emissions: What Are the Options?, 36 B.C. ENVTL. AFF. L. REV. 1, 20 (2009).

174. W. VA. CODE ANN. § 22-6-1(v) (West Supp. 2013).

175. See id. Colorado provides the following definitions of "waste" for oil and gas conservation purposes:

(11) "Waste", as applied to gas, includes the escape, blowing, or releasing, directly or indirectly into the open air, of gas from wells productive of gas only, or gas in an excessive or unreasonable amount from wells producing oil, or both oil and gas; and the production of gas in quantities or in such manner as unreasonably reduces reservoir pressure or unreasonably diminishes the quantity of oil or gas that ultimately may be 
produced; excepting gas that is reasonably necessary in the drilling, completing, testing, and in furnishing power for the production of wells.

(12) "Waste", as applied to oil, includes underground waste; inefficient, excessive, or improper use or dissipation of reservoir energy, including gas energy and water drive; surface waste; open-pit storage; and waste incident to the production of oil in excess of the producer's aboveground storage facilities and lease and contractual requirements, but excluding storage, other than open-pit storage, reasonably necessary for building up or maintaining crude stocks and products thereof for consumption, use, and sale.

(13) "Waste", in addition to the meanings as set forth in subsections (11) and (12) of this section, means:

(a) Physical waste, as that term is generally understood in the oil and gas industry;

(b) The locating, spacing, drilling, equipping, operating, or producing of any oil or gas well or wells in a manner which causes or tends to cause reduction in quantity of oil or gas ultimately recoverable from a pool under prudent and proper operations or which causes or tends to cause unnecessary or excessive surface loss or destruction of oil or gas;

(c) Abuse of the correlative rights of any owner in a pool due to nonuniform, disproportionate, unratable, or excessive withdrawals of oil or gas therefrom, causing reasonably avoidable drainage between tracts of land or resulting in one or more producers or owners in such pool producing more than his equitable share of the oil or gas from such pool.

Colo. Rev. Stat. ANN. § 34-60-103 (West Supp. 2013) (emphasis added).

The Oklahoma legislature has defined waste in a number of different statutes, each having some slight variation from the others, but all defined to include the "ordinary" meaning of the term:

The term "waste", as applied to gas, in addition to its ordinary meaning, shall include the inefficient or wasteful utilization of gas in the operation of oil wells drilled to and producing from a common source of supply; the inefficient or wasteful utilization of gas from gas wells drilled to and producing from a common source of supply; the production of gas in such quantities or in such manner as unreasonably to reduce reservoir pressure or unreasonably to diminish the quantity of oil or gas that might be recovered from a common source of supply; the escape, directly or indirectly, of gas from oil wells producing from a common source of supply into the open air in excess of the amount necessary in the efficient drilling, completion or operation thereof; waste incident to the production of natural gas in excess of transportation and marketing facilities or reasonable market demand; the escape, blowing or releasing, directly or indirectly, into the open air, of gas from wells productive of gas only, drilled into any common source of supply, save only such as is necessary in the efficient drilling and completion thereof; and the unnecessary depletion or inefficient utilization of gas energy contained in a common source of supply.

OKLA. Stat. ANN. tit. 52, § 86.3 (West 2011) (emphasis added); see also id. $\S 86.2$ (similar concepts applied to waste of oil).

The term waste, as used herein in addition to its ordinary meaning, shall include escape of natural gas in commercial quantities into the open air, the intentional drowning with water of a gas stratum capable of producing gas in commercial quantities, underground waste, the permitting of any natural gas well to wastefully burn and the wasteful utilization of such gas.

Id. § 237; see also id. § 273 (similar concepts applied to waste of oil).

Finally, Kansas defines waste in the natural gas context as follows:

The term "waste", in addition to its ordinary meaning, shall include economic waste, underground waste and surface waste. Economic waste shall mean the use of natural gas in any manner or process except for efficient light, fuel, carbon black manufacturing and 
waste, but the narrower traditional view of the term that is implicated under the Marketable Product Rule.

Physical waste is generally defined as "the loss of oil or gas that could have been recovered and put to use," 176 and further described to include the "failure to recover the maximum quantity [of oil or gas] which theoretically could be produced." 177 Accordingly, any circumstance that precludes recovery of all the oil or gas that would otherwise be economically recoverable from a given property may be said to cause physical waste of those hydrocarbon resources.

\section{The Legislatures' Role in Establishing Public Policy Against Waste}

After declaring the importance of maximizing recovery of hydrocarbon resources, and articulating the strong public policy against waste, the legislatures of the Marketable Product Rule states went even further by establishing conservation agencies that were then given, as a principal duty, the responsibility to prevent waste of the state's oil and gas resources. ${ }^{178}$ These agencies were given authority to prescribe rules and regulations in support of the legislatures' stated public policies on waste, ${ }^{179}$ and to impose fines and penalties on those who failed to comply. ${ }^{180}$ In a further effort to avoid waste and to maximize hydrocarbon recovery, the legislature of each Marketable Product Rule state even crafted exemptions from severance tax for marginal wells, which helps extend their economic life. ${ }^{181}$ In sum, the legislature of each

repressuring, or for chemical or other processes by which such gas is efficiently converted into a solid or a liquid substance.

KAN. STAT. ANN. § 55-702 (2012); see also id. § 55-602 (similar definition for waste of crude oil).

176. 8 MARTIN \& KRAMER, supra note 11 , at 1133.

177. Id. at 765; see also supra note 175 (showing emphasized portions of statutory waste definitions consistent with this general definition).

178. See, e.g., Colo. Rev. Stat. AnN. § 34-60-117(1) (West 2014); Kan. Stat. AnN. § 55-704 (2012); OKLa. Stat. ANN. tit. 52, § 86.2 (West 2011); W. VA. Code AnN. § 22C-9-4(e), (f) (West 2006).

179. See, e.g., Colo. Rev. StAT. AnN. § 34-60-105(1) (West 2014); KAN. Stat. ANN. § 55-704 (2012); OKLA. StAT. ANN. tit. 52, § 86.2 (West 2011); W. VA. CodE ANN. § 22C-9-5 (West 2006).

180. See, e.g., Colo. Rev. StAT. ANN. § 34-60-121(1) (West 2014); KAN. STAT. ANN. § 55-708 (2012); OKLA. Stat. ANN. tit. 52, § 143 (West 2011); W. VA. CodE ANN. § 22C-9-14 (West 2006).

181. See, e.g., Colo. Rev. Stat. AnN. § 39-29-105(1)(b) (West Supp. 2013); Kan. Stat. AnN. $\S 79-4217$ (b)(1)(D) (West Supp. 2013); OKLA. STAT. AnN. tit. 68, § 1001.3a (West Supp. 2014); W. VA. CODE ANN. § 11-13A-3a(a)(2) (West 2010). While the other states' legislatures implicitly seek to prevent premature abandonment of recoverable hydrocarbon reserves through their severance tax exemptions, the application of Oklahoma's exemption is expressly limited to an "economically atrisk oil or gas lease," defined as one reaching the type of economic limit that would trigger lease 
Marketable Product Rule state has gone to considerable effort to declare and emphasize the importance of encouraging the development, and the efficient, thorough, recovery of its limited energy resources.

Nevertheless, these same legislative bodies have endeavored to strike a balance between maximizing hydrocarbon recovery and protecting other important public interests. For example, each of these states has charged its conservation agency with limiting hydrocarbon production when necessary to safeguard health and environmental concerns such as safe drinking water. ${ }^{182}$ In response, these agencies have established detailed requirements for casing oil and gas wells to protect aquifers; ${ }^{183}$ they have imposed rigorous requirements for casing integrity tests prior to permitting underground injection of fluids; ${ }^{184}$ and they have promulgated regulations restricting production when it would cause the release of harmful substances into the environment. ${ }^{185}$ Likewise, the desire to produce more oil and gas has often been forced to give way to the need to ensure a safe work environment for those employed in the field. ${ }^{186}$

Viewed collectively, these facts demonstrate that the legislature of each oil and gas producing state has established a comprehensive statutory scheme under which the general prohibition against waste is balanced with exceptions that might limit recovery of oil and gas resources when necessary to promote other important public interests such as protection of health, safety, and the environment. This prerogative to declare the public policy of the given state, and to delineate the exceptions thereto, generally lies exclusively with the legislature, not with the judiciary. ${ }^{187}$ Once the legislature has established

termination due to a failure to produce in paying quantities. OKLA. STAT. AnN. Tit. 68, $\S$ 1001.3a.A.1 (West Supp. 2014).

182. See, e.g., ColO. Rev. Stat. ANN. § 34-60-106(2)(d) (West Supp. 2013); KAn. StAT. ANN. $\S 55-152$ (West Supp. 2013); OKLA. Stat. AnN. tit. 52, § 139 (West Supp. 2013); W. VA. CodE ANN. § 22-6-2 (West Supp. 2013).

183. See, e.g., 2 Colo. Code RegS. § 404-1:317 (2014); Kan. Admin. Regs. § 82-3-106 (2014); OKLA. ADMIN. CODE § 165:10-3-4 (2014); W. VA. CODE R. § 35-4-7, 11 (2014).

184. See, e.g., 2 Colo. Code Regs. § 404-1:326 (2014); Kan. AdMin. Regs. § 82-3-407 (2014); OKLA. ADMIN. CODE § 165:10-5-6 (2014); W. VA. CODE R. § 35-4-7.3 (2014).

185. See, e.g., 2 Colo. Code RegS. § 404-1:324A (2014); KAN. Admin. RegS. § 82-3-104 (2014); OKLA. ADMIN. CODE § 165:10-7-5 (2014); W. VA. CODE R. § 35-4-7.2 (2014).

186. See, e.g., Colo. Rev. STAT. ANN. § 34-60-106(10), (11)(a)(II) (West Supp. 2013); OKLA. Stat. ANN. tit. 52, § 149 (West 2011); W. VA. Code ANN. § 22-6-2(c)(9) (West Supp. 2013).

187. See, e.g., McCutchen v. City of Fort Smith, 425 S.W.3d 671, 681 (Ark. 2012); Stevenson v. Superior Court, 941 P.2d 1157, 1161 (Cal. Ct. App. 1997) ("tethering public policy to specific constitutional or statutory provisions serves ... to avoid judicial interference with the legislative domain ...."); Martin v. People, 27 P.3d 846, 848 (Colo. 2001); Phoenix Ins. Co. v. Rosen, 949 
public policy on a matter, the courts are generally bound to adhere to that policy. ${ }^{188}$ Thus, when the legislature has expressly set forth the public policy against waste, and carefully enumerated the exceptions to that policy, the judiciary should be extremely circumspect about departing from decades of precedent settling the meaning of common contractual terms like the royalty clauses that gave rise to the Marketable Product Rule. Likewise, courts should be particularly reluctant to embark on journeys to craft new doctrines, like the Marketable Product Rule, that conflict with the legislature's determination of public policy and frustrate the extraordinary efforts undertaken by the legislative body to achieve its policy goals, especially when the plain language of the underlying royalty clauses has yielded a result consistent with the legislature's stated policy goals for decades prior to the adoption of Marketable Product Rule jurisprudence. ${ }^{189}$

N.E.2d 639, 645 (Ill. 2011) (““[w]hen the legislature has declared, by law, the public policy of the State, the judicial department must remain silent...." (alteration in original) (quoting Reed v. Farmers Ins. Grp., 720 N.E.2d 1052, 1057 (Ill. 1999))); State v. Hendrix, 218 P.3d 40, 43 (Kan. 2009) superseded by statute, Kan. Stat. Ann. § 21-5221 (Supp. 2013) (superseding the "use of force" definition but not disturbing the rule that the legislature determines public policy); Duncan v. Oklahoma Dep't of Corr., 95 P.3d 1076, 1079 (Okla. 2004); Weaver v. Harpster, 975 A.2d 555, 563 (Pa. 2009) ("In our judicial system, the power of the courts to declare pronouncements of public policy is sharply restricted. Rather, it is for the legislature to formulate the public policies of the Commonwealth.”); Smith v. Gore, 728 S.W.2d 738, 746-47 (Tenn. 1987) (public policy to be determined by legislature; judicial declaration of public policy a "usurpation" of legislative authority); FM Props. Operating Co. v. City of Austin, 22 S.W.3d 868, 873 (Tex. 2000) ("Generally, commentators have defined legislative power as the power to make rules and determine public policy." (citing Sotirios A. BARBER, THE CONSTITUTION AND DELEGATION OF CONGRESSIONAL POWER 38 (1975))); Flynn v. Dep't of Admin., 576 N.W.2d 245, 252 (Wis. 1998) (legislature, not courts, determines public policy).

188. See, e.g., Bhd. of Locomotive Firemen \& Enginemen v. Chicago, R.I. \& P.R. Co., 393 U.S. 129, 138 (1968) ("'P]ublic policy can, under our constitutional system, be fixed only by the people acting through their elected representatives."); Miles v. Idaho Power Co., 778 P.2d 757, 762 (Idaho 1989); Roanoke Agency, Inc. v. Edgar, 461 N.E.2d 1365, 1371 (Ill. Ct. App. 1984) (courts must defer to legislature's pronouncement of public policy); A.B. v. State, 949 N.E.2d 1204, 1225 (Ind. 2011); Wicina ex rel. Wicina v. Strecker, 747 P.2d 167, 171 (Kan. 1987) ("Courts must respect legislative expressions when determining or when forming public policy."); Budding v. SSM Healthcare Sys., 19 S.W.3d 678, 682 (Mo. 2000).

189. See Restatement (SECOND) OF CONTRACts: InTERPRETATION FAVORING THE Public $\S$ 207 (1981) ("In choosing among the reasonable meanings of a promise or agreement or a term thereof, a meaning that serves the public interest is generally preferred."); see also Time Warner Entm't Co., L.P. v. Everest Midwest Licensee, L.L.C., 381 F.3d 1039, 1045 (10th Cir. 2004) (applying Kansas law in telecommunications contract dispute and relying on section 207 of the Restatement to support a contract interpretation that favored the public interest); Sachtjen v. Am. Family Mut. Ins. Co., 49 P.3d 1146, 1150 \& n.7 (Colo. 2002) (in an insurance context, a meaning that supports the public interest is preferred).

In Classen v. Fed. Land Bank of Wichita, 617 P.2d 1255 (1980), the Kansas Supreme Court recognized its duty to consider the public policy against waste in interpreting oil and gas instruments: 


\section{The Marketable Product Rule Violates the Public Policy AGAINST WASTE}

Nevertheless, courts adopting the Marketable Product Rule have uniformly failed in their responsibility to enforce the public policy against waste, finding ambiguity where it need not be found, and crafting a solution that promotes physical waste of natural gas resources. ${ }^{190}$ Waste results from operation of the habendum clause in the underlying oil and gas lease, which establishes the duration of the lease. A typical habendum clause provides for a fixed term of anywhere from a few months to several years, with the possibility of indefinite duration for "as long thereafter as oil or gas is produced in paying quantities." "Paying quantities" is generally defined as oil or gas production "sufficient to yield a return in excess of operating costs," without regard to drilling and other capital costs, and even though "the undertaking considered as a whole may ultimately result in a loss." 192

It is now common knowledge that this tired old world of ours, and our country in particular, is faced with a frightening and progressive energy crisis due principally to a shortage of petroleum reserves. This country cannot now, and will not in the foreseeable future be able to, produce even the minimum requirements of oil and gas needed to preserve our existence. With every increase in production we suffer a corresponding decrease in our petroleum energy reserves. Under these severe conditions we feel that it is incumbent on all persons, including this court, to assist in the preservation and conservation of our natural petroleum resources including production methods which will minimize waste.

Id. at 1262 (emphasis added). Under that view, perhaps Sternberger would have been decided differently if the court had considered how its confirmation of the Marketable Product Rule in Kansas jurisprudence would lead to waste of limited hydrocarbon resources.

190. Note that a few state legislatures have enacted statutes that essentially codify some form of the Marketable Product Rule, usually subject to certain express language in the governing oil and gas leases. See, e.g., Mich. Comp. LAws AnN. § 324.61503b (West Supp. 2014); Nev. Rev. StAT. ANN. § 522.115.1(b), 3 (West Supp. 2014); Wyo. STAT. AnN. § 30-5-304(a)(ii), (vi) (West 2007). While these types of provisions cut against a state's public policy regarding waste, the balancing of such policy objectives is inherently a function of the legislature, and it is the prerogative of that body, rather than the judiciary, to make such exceptions. See supra notes 187-188 and accompanying text.

191. Wellman v. Energy Res., Inc., 557 S.E.2d 254, 260 n.2 (W. Va. 2001) (quotation omitted); see also Levin v. Maw Oil \& Gas, LLC, 234 P.3d 805, 809 (Kan. 2010); Pack v. Santa Fe Minerals, 869 P.2d 323, 326 (Okla. 1994). Even if the habendum clause omits the express reference to "paying quantities," such a requirement is generally presumed. See, e.g., Pray v. Premier Petrol., Inc., 662 P.2d 255, 257 (Kan. 1983).

192. MARTIN \& KRAMER, supra note 11, at 821; see also Reese Enters., Inc. v. Lawson, 553 P.2d 885, 895 (Kan. 1976) ("It is generally accepted that the phrase 'in paying quantities' in the 'thereafter' provision (extension clause) of an oil and gas lease's habendum clause means production of quantities of oil or gas sufficient to yield a profit to the lessee over operating expenses, even though the drilling costs, or equipping costs, are never recovered, and even though the undertaking 
A paying quantities analysis begins with the revenues derived from the contractual working interest under the original lease, with no reduction for any outstanding overriding royalty interests or other payments out of the lessee's share of production. ${ }^{193}$ From that revenue stream, deductions are taken for the direct costs of production. ${ }^{194}$ Direct costs generally include costs or expenses for labor, taxes, electricity, fuel, and other items incurred to produce and market hydrocarbons from the leased premises. ${ }^{195}$

When gas is sold off the leased premises, the lessee's revenue stream is also reduced by the post-production costs incurred to gather, treat, and transport the gas to the point of sale. ${ }^{196}$ In non-Marketable Product Rule jurisdictions, the lessor bears its proportionate share of those postproduction costs. However, in Marketable Product Rule states, the lessee's share of production revenue is further burdened with the lessor's share of post-production costs from the wellhead to the point where the gas is placed in marketable condition, or even further to a marketable location (for Colorado) or the ultimate point of sale (for West Virginia). Since this shifting of post-production costs is not accompanied by any increase in the lessee's production revenue, in most cases the unavoidable result is that the underlying lease will terminate due to cessation of production in paying quantities at an earlier point in time, and with less overall recovery of natural gas, than if the lessor had been required to bear its share of post-production costs. ${ }^{197}$

as a whole may thus result in a loss to the lessee."); Smith v. Marshall Oil Corp., 85 P.3d 830, 833 (Okla. 2004) (supporting the idea that "paying quantities" means producing enough oil or gas to provide a profit in excess of the operating expenses).

193. Reese Enters., 553 P.2d at 898; Transp. Oil Co. v. Exeter Oil Co., 191 P.2d 129, 133-34 (Cal. Ct. App. 1948); Clifton v. Koontz, 325 S.W.2d 684, 693 (Tex. 1959). For a thorough treatment of the paying quantities analysis, see Douglas H. Gross, Meaning of "Paying Quantities" in Oil and Gas Lease, 43 A.L.R.3d 8 (Supp. 2014).

194. Reese Enters., 553 P.2d at 898; see also Whitaker v. Texaco, Inc., 283 F.2d 169, 176 (10th Cir. 1960) (applying Oklahoma law); Lowther Oil Co. v. Miller-Sibley Oil Co., 44 S.E. 433, 507-08 (W. Va. 1903).

195. See generally Gross, supra note 193, § 6 .

196. Reese Enters., 553 P.2d at 898 (paying quantities analysis includes deduction of costs to market gas); Clifton, 325 S.W.2d at 691; Barbour, Stedman \& Co. v. Tompkins, 93 S.E. 1038, 1040 (W. Va. 1917) ("If the quantity be sufficient to warrant the use of the gas in the market, and the income therefrom is in excess of the actual marketing cost, the production satisfies the term 'in paying quantities."').

197. See John S. Lowe et al., CASES AND Materials on Oil and Gas LaW 341 (quoting W.L. SuMmers, THE LAW OF OIL AND GAS $\S 589 \mathrm{~B}$ (John S. Lowe update ed.) (Version 1954 and Thomson 2007)) ("One may also argue that adopting a rule that the implied covenant to market requires the lessee to pay all expenses of developing a commercial product is bad policy. Adoption 
This point can be illustrated with a simple example. Assume a gas lease with a $25 \%$ lessor's royalty, and total revenue attributable to the contractual working interest of $\$ 20,000$ over the relevant period of time. Also assume that direct costs of production to get the gas to the surface are $\$ 10,000$; post-production costs from the wellhead to the point of sale are \$10,000; and the gas first reaches "marketable condition" at the point of sale. In a non-Marketable Product Rule state, the lessee bears all costs of production, but the lessor bears its proportionate share of postproduction costs. In this example, the lessor would bear $25 \%$ of the $\$ 10,000$ in post-production costs, leaving the lessee responsible for the remaining expenses of $\$ 10,000$ in production costs and $\$ 7,500$ in postproduction costs. That yields a profit to the lessee of $\$ 2,500(\$ 20,000$ in revenue, less $\$ 17,500$ in costs), and the lease is maintained by production in paying quantities.

Considering that same scenario in a Marketable Product Rule state, the lessee bears all production and post-production costs. Thus the lessee is responsible for $\$ 10,000$ in production costs and all $\$ 10,000$ in postproduction costs, which wipes out the lessee's profit. Since production in paying quantities has ceased, absent some other lease savings provision, the lease generally terminates. ${ }^{198}$ Since it may be observed that a lessor rarely takes the actions necessary to qualify under state law to become the operator and take over operation of the lease, ${ }^{199}$ the wells

of such a rule is likely to mean that wells will be plugged and abandoned sooner than they would otherwise.").

198. Although there is some distinction among the Marketable Product Rule states regarding application of the lease's habendum clause upon cessation of production in paying quantities, the difference generally turns on whether the law requires actual production in paying quantities, or the capability to produce in paying quantities. See Davis v. Cramer, 837 P.2d 218, 222 (Colo. Ct. App. 1992) (habendum clause satisfied by discovery of commercial quantities of hydrocarbons); Pack v. Santa Fe Minerals, 869 P.2d 323, 327 (Okla. 1994) (capability of production in paying quantities satisfies habendum clause); Goodwin v. Wright, 255 S.E.2d 924, 925-26 (W. Va. 1979) (production in paying quantities, or diligent efforts to secure same, required to satisfy habendum clause). Regardless of whether a state looks to actual production or capability of production in evaluating operation of the habendum clause, the same result ensues when the issue is not lack of physical production, but rather the resulting economics; when the Marketable Product Rule accelerates the point of unprofitable production, the lease is neither actually producing, nor capable of producing, in paying quantities.

199. This is largely an empirical observation; however, as one metric by which this proposition may be evaluated, consider that a review of the list of active oil and gas operators in Kansas reveals out of over 2,400 operators, less than 400 are individuals, family-related trusts, or similar entities that appear (from the name) to potentially be lessors who took over wells on their property. See Kansas Oil Operators, KANSAS CORPORATION COMMISSION, http://www.kcc.state.ks.us /conservation/oil_license.cgi (last visited Oct. 24, 2014) (follow "list of active operators only" hyperlink). Obviously, this number could be lower than actual to the extent lessors took over operations under an entity name; and the number could be too high to the extent that a number of the 
on the lease are abandoned, leaving in the ground potentially substantial quantities of natural gas that would have been recovered had the Marketable Product Rule not been applied. ${ }^{200}$

Other than the lessors, everyone suffers under the Marketable Product Rule. The lessees clearly suffer by being burdened with additional costs that were not bargained for under the leases, and through the loss of additional reserves that would have been economically recoverable in a non-Marketable Product Rule jurisdiction. The public as a whole suffers when those natural gas reserves, prematurely abandoned under the Marketable Product Rule, never make it to market, thereby resulting in the potential for higher prices due to reduced supply, higher trade imbalances and dependence on less reliable foreign energy supplies due to the need to import replacement energy sources, and perhaps the use of less environmentally friendly sources of energy to replace those lost reserves. ${ }^{201}$ In a rising market, even the lessors may suffer loss; if the Marketable Product Rule triggers premature lease termination and abandonment, the lessors lose the opportunity to receive royalty on the otherwise recoverable gas. If the price for natural gas rises significantly thereafter, it is certainly conceivable that the lessors might have received more royalty overall by bearing their share of post-

listed individuals are simply operators, rather than lessors who took over their own operations. In any event, it is the order of magnitude of the number that is most informative. The Kansas Geological Survey shows that, as of August 7, 2014, there were almost 100,000 producing oil and gas wells in Kansas. See Oil and Gas Well Statistics for Kansas, Kansas GeOLOGICAL SuRveY, http://www.kgs.ku.edu/PRS/wellStats.html (last visited Oct. 24, 2014). Assuming that 400 is an even remotely accurate estimate of the number of former lessors who took over wells, and assuming the average lease may have a handful of unplugged, potentially productive wells thereon, the data supports the notion that it is a rarity that a lessor operates wells under any circumstances.

200. In Royalty Jurisprudence: A Tale Of Two States, Professor David Pierce analyzes the glaring disparities between Texas' plain-language approach to "at the well" gas royalty provisions and Colorado's continual expansion of its Marketable Product Rule jurisprudence when applied to the same royalty language. Pierce, supra note 140. Professor Pierce notes that the Marketable Product Rule battles are a classic example of the conflict predicted by his "royalty value theorem," $i d$. at 358, which states, "When compensation under a contract is based upon a set percentage of the value of something, there will be a tendency by each party to either minimize or maximize the value." Id. at 352 .

Along with his royalty value theorem analysis, Professor Pierce also postulated that royalty litigation, like that involved in Marketable Product Rule disputes, is a "zero-sum game," id. at 34849 , in which the courts engage in "a re-slicing of the finite production pie." Id. at 349 . While that may sometimes be the case, this author suggests that any time the dispute has the potential to result in a reduction in the lessee's production revenue, or an increase in the lessee's share of production or post-production costs, the resulting acceleration of lease termination due to premature cessation of production in paying quantities results in a shrinking pie. Thus, the contest is not always a zero-sum game, but sometimes one which results in a net negative overall, with the only question being whether the lessee bears all the loss, or whether the lessor also suffers from his self-inflicted wounds.

201. See Burns, supra note 173, at 624 . 
production costs and receiving royalty on substantially more production, than they would by shifting their post-production costs to the lessee and producing less. And finally, the Marketable Product Rule imposes a burden on future oil and gas lessors in that, all other things being equal, a potential lessee can afford to offer a higher royalty to a lessor in a nonMarketable Product Rule jurisdiction. While this burden is difficult to quantify, it is intuitive that a lessee entering a Marketable Product Rule state will have to figure the additional post-production costs into its economics when determining the royalty burden it is willing to bear to obtain leases. Accordingly, the Marketable Product Rule is a regressive doctrine that benefits past generations of lessors by essentially rewriting more favorable lease terms on their behalf, while shifting the costs to lessees, future lessors, and the general public.

\section{CONCLUSION}

The Marketable Product Rule represents an unnecessary reinterpretation of established oil and gas lease language, the result of which promotes waste of natural gas resources in violation of the public policy of every state that has adopted the Rule. To correct this aberration, Marketable Product Rule courts need to be more circumspect about the overall consequences of their doctrine. Crafted with a myopic view toward protecting weak landowners from the overreaching of "Big Oil," the Marketable Product Rule reflects a paternalistic solution to a largely bygone era when landowners lacked ready access to legal expertise on oil and gas leasing. While the oil and gas industry has by no means been purged of its inherent self-interest, nor has it been immunized against sharp practices, the abundant availability of legal services to advise potential lessors in an oil and gas transaction weighs heavily against the continued role of the courts as post-hoc advocates for the unwitting landowner. Moreover, there is nothing inherently sinister or misleading about language that values royalty "at the well;" on the contrary, despite the Marketable Product Rule courts' inability to understand that phrase, even the casual reader will probably get the idea that a royalty clause that values royalty "at the well" might mean that the value of the lessor's royalty will be determined at the well.

Instead of fixating on the lessor, courts need to consider the broader public policies implicated by their decisions. An industry that is critical to the economic security of this country has been built on the wellestablished foundation that certain common royalty provisions yield predictable results; but after half a century or more of predictability, the 
Marketable Product Rule has injected extraordinary uncertainty into the interpretation of contracts on which many have staked their livelihood, and essentially turned unsuspecting lessees into guarantors of the quality of gas produced from their leases. Prior to the adoption of the Marketable Product Rule, royalty clause jurisprudence was generally harmonized with the states' public policies against waste. However, the Rule itself frustrates those polices by promoting waste of natural gas resources. This in turn denies the public important quantities of one of the most environmentally friendly fossil fuel resources, as well as an abundant alternative to oil imported from politically hostile or unstable parts of the world. Finally, the Marketable Product Rule provides a windfall to prior generations of lessors at the expense of future lessors, who must bear the burden of reduced royalty percentages in comparison to lessors in non-Marketable Product Rule states, as lessees adjust their leasehold economics to account for the added burdens and uncertainties imposed under the Rule.

Rather than engage in the linguistic gymnastics required to conclude that "at the well" does not mean "at the well," and use implied covenants to improperly negate express lease language, Marketable Product Rule courts need to revisit the fundamentals of contract interpretation and their own historical jurisprudence on the proper role of covenants implied in fact to reign in the unprincipled consequences of the Rule. These courts would do well to consider their role in supporting the public policy against waste articulated by their respective legislatures, and recognize that by promoting the premature abandonment of otherwise recoverable hydrocarbon reserves, the Marketable Product Rule inflicts harm on lessees, many lessors, and the public as a whole. 